\title{
Geologia e Caracterização Química do Magmatismo Peralcalino Ultrapotássico do Enxame de Diques Manaíra-Princesa Isabel, Província Borborema
}

\author{
Geology and Chemical Characterization of the Ultrapotassic Peralkaline \\ Magmatism of the Manaíra-Princesa Isabel Dike Swarm, Borborema Provine
}

\author{
Maria Helena Bezerra Maia de Hollanda' (hollanda@usp.br), Carolina Pelaéz Mejía' (caropelaez@usp.br), \\ Carlos José Archanjo' (archan@usp.br), Richard Armstrong² (richard.armstrong@anu.edu.au) \\ 'Departamento de Mineralogia e Geotectônica - Instituto de Geociências - USP \\ R. do Lago 562, CEP 05508-080, São Paulo, SP, BR \\ ${ }^{2}$ Research School of Earth Sciences - Australian National University, Canberra, AU
}

Recebido em 10 de dezembro de 2008; aceito em 30 de julho de 2009

\section{RESUMO}

O enxame de diques ácidos da região de Manaíra-Princesa Isabel aflora no estado da Paraíba, geologicamente inserido no domínio Alto Pajeú da Zona Transversal (Província Borborema, NE do Brasil). O enxame compreende principalmente nefelina sienitos a sienitos saturados em sílica, com afinidade peralcalina ultrapotássica e, subordinadamente, álcali-granitos com afinidade metaluminosa. A assembleia mineral é dominada por microclina e anfibólio \pm piroxênios sódicos nos termos sieníticos, enquanto mg-biotita está restrita aos álcali-granitos. Anfibólio é dominantemente de composição magnésio-riebeckita, identificado nos subenxames de Manaíra, Princesa Isabel e Tavares; enquanto o piroxênio é egirina-augita (subenxames Manaíra e Tavares), passando a composições de egirina nas bordas, quando zonados. A assinatura geoquímica-isotópica mostra forte enriquecimento em elementos incompatíveis, associado à marcante depleção em $\mathrm{Nb}$, a razões ${ }^{87} \mathrm{Sr} /{ }^{86} \mathrm{Sr}$ radiogênicas e $\varepsilon_{\mathrm{Nd}}$ negativos. Essas feições sugerem manto litosférico enriquecido como fonte comum para os diques, provavelmente modificado por um componente de subducção antigo, como indicado pelas idades $\mathrm{T}_{\mathrm{DM}}$ paleoproterozoicas. Razões isotópicas de $\mathrm{Pb}$ mostram claro desacoplamento com respeito às razões isotópicas de $\mathrm{Sr}$ e $\mathrm{Nd}$, com valores significativamente mais baixos que a média dos valores crustais, sugerindo a participação de um componente não radiogênico interagindo com a fonte mantélica, enriquecida. A ocorrência de magmatismo fissural, intraplaca, com provável idade U-Pb em zircão de c. $600 \mathrm{Ma}$, define contextos geodinâmicos contrastantes. Esse contraste refere-se à contemporaneidade entre um cenário de relativa quiescência tectônica (a colocação dos diques em crosta fria) se contrapondo com a intensa atividade tectonomagmática, correlacionada à orogênese Brasiliana, desenvolvendo-se em blocos crustais lateralmente contíguos na porção central da Zona Transversal.

Palavras-chave: Província Borborema; Zona transversal; Magmatismo peralcalino ultrapotássico; Manto litosférico enriquecido.

\section{ABSTRACT}

The Manaíra-Princesa Isabel dike swarm forms one of the most expressive examples of Neoproterozoic (c. $600 \mathrm{Ma}$ ) peralkaline magmatism in the Borborema Province (NE Brazil). It consists of about a hundred NE-trending bodies intrusive in older, Neoproterozoic porphyritic granites (Princesa Isabel and Tavares plutons), and orthogneisses and low-grade metasediments of the Eo-neoproterozoic Riacho Gravatá complex. The dike swarm includes mostly silica-saturated syenites, with potassic to ultrapotassic, peralkaline affinity, containing microcline and sodic amphibole \pm pyroxene as the main mineral assemblage. Amphibole is dominantly Mg-riebeckite (Manaíra, Princesa Isabel and Tavares sub-swarms), whereas pyroxene is mainly aegirine-augite (Manaíra and Tavares sub-swarms). A minor set of dikes from this swarm is slightly metaluminous with Mg-biotite as the major mafic phase. Geochemical and isotopic signatures indicate strong enrichment in incompatible elements ( $\mathrm{Rb}, \mathrm{Ba}, \mathrm{K}, \mathrm{Th}, \mathrm{U})$, in association with a negative $\mathrm{Nb}$ anomaly, and strongly radiogenic ${ }^{87} \mathrm{Sr} /{ }^{86} \mathrm{Sr}$ and ${ }^{143} \mathrm{Nd} /{ }^{144} \mathrm{Nd}$ (= negative $\varepsilon_{\mathrm{Nd}}$ values) initial ratios. These features suggest a common source, which was probably an 
enriched lithospheric mantle reservoir, chemically modified by an ancient subduction component inferred to be Paleoproterozoic from $\mathrm{T}_{\mathrm{DM}}$ model ages. Conversely, $\mathrm{Pb}$ isotopic ratios lower than average crustal values indicate the influence of a non-radiogenic component interacting with the enriched mantle source. A SHRIMP U-Pb age of c. $600 \mathrm{Ma}$ obtained for the Manaíra-Princesa Isabel dike swarm defines an important crustal exhumation period which was relatively synchronous with intensive tectonomagmatic activity related to the Brasiliano orogeny, which occurred in distinct structural domains within the Transverse Zone of the Borborema Province.

Keywords: Borborema Province; Transversal zone; Ultrapotassic peralkaline magmatism; Enriched litospheric mantle.

\section{INTRODUÇÃO}

A composição geoquímica de magmas de afinidade alcalina é controlada por seu ambiente tectônico, mais precisamente pelas características químicas de suas fontes, sejam estas o manto litosférico (ou astenosférico) ou a crosta continental. A diversidade de fontes que contribuem na gênese desses magmas reflete-se na heterogeneidade de sua assinatura geoquímica e, especialmente, isotópica (Bonin, 2007). Essa heterogeneidade pode ainda estar relacionada a processos petrogenéticos posteriores à fusão parcial da fonte, os quais podem modificar as características originais do magma, impossibilitando a definição precisa da natureza da fonte. Um desses processos é assimilação durante ascensão na crosta quando, a depender da extensão da contaminação, as características geoquímico-isotópicas de magmas derivados de fusão astenosférica poderão representar maior ou menor influência de valores tipicamente crustais. Em se tratando de magmas originados a partir da fusão de manto litosférico, anomalamente enriquecido, a questão é ainda mais problemática visto as similaridades entre este reservatório e a crosta. Nesse sentido, a geoquímica (elementar e isotópica) pode fornecer resultados ambíguos, onde não é possível definir com clareza a tipologia da fonte.

Magmas com afinidade alcalina têm sido interpretados como derivados de fusão parcial, em pequenas proporções, de: 1. manto litosférico enriquecido em elementos incompatíveis (p.ex., Dawson, 1987), 2. manto astenosférico empobrecido em elementos incompatíveis (p.ex., Fitton, 1987), ou 3. interação de líquidos astenosféricos com o manto litosférico sobrejacente (p.ex., Menzies, 1987). Origem a partir de um "manto metassomatizado" é uma interpretação frequente em trabalhos sobre magmas alcalinos a peralcalinos. $\mathrm{O}$ termo foi introduzido explicitamente por Bailey (1972) para explicar as características químicas particulares desse tipo de magmatismo, e correlacioná-lo a ambientes continentais específicos. Evidências que apontem para essa origem são reconhecidas por: 1. mudanças mineralógicas/texturais visíveis, com neoformação de fases hidratadas ricas em elementos incompatíveis - metassomatismo patente, no sentido de Dawson (1984) (também Nielson e Noller, 1987; Wilshire, 1987), ou 2. enriquecimento anômalo em elementos incompatíveis $[\mathrm{K}, \mathrm{Rb}, \mathrm{Sr}$,
$\mathrm{Ba}, \mathrm{Th}, \mathrm{U}, \mathrm{ETR}$ leves (e menos frequentemente $\mathrm{Nb}, \mathrm{Zr}$, $\mathrm{Ti}, \mathrm{P})$ ] relativo às abundâncias primitivas/condríticas, sem necessariamente estar acompanhado de evidências petrográficas - metassomatismo crítico (Dawson, 1984; Nielson e Noller, 1987; Wilshire, 1987), também referido como metassomatismo potássico por Menzies et al. (1987). As abundâncias anômalas nesses elementos estariam vinculadas à participação de um agente metassomático, o qual poderia ser representado por fusões silicáticas ou fluidos aquosos(/carbonatados) interagindo com o manto peridotítico originalmente empobrecido, mas fértil (Roden e Murthy, 1985; Tatsumi e Eggins, 1995). Zonas de subducção e riftes intracontinentais representariam, portanto, cenários geodinâmicos propícios para esse processo.

\section{CONTEXTO GEOLÓGICO REGIONAL}

A Província Borborema é definida como uma entidade tectônica situada no Nordeste do Brasil, caracterizada pela atuação do ciclo Brasiliano/Pan-africano (Almeida et al., 1981). A feição mais marcante da orogênese brasiliana na Província Borborema é o volumoso magmatismo, dominantemente granítico, temporal e espacialmente associado a extensas zonas de cisalhamento que compartimentam toda a província. Dados geocronológicos, isotópicos e gravimétricos permitiram a subdivisão da Província Borborema em subprovíncias:

1. Setentrional, situada a norte do Lineamento Patos, onde predominam rochas paleoproterozoicas envolvendo pequenos núcleos arqueanos variavelmente retrabalhados pelo ciclo Brasiliano, bem como rochas juvenis atribuídas a um arco magmático continental neoproterozoico (Jardim de Sá, 1994; Fetter et al., 2003; Dantas et al., 2004).

2. Meridional, entre o Lineamento Pernambuco e a margem norte do Craton São Francisco, onde predominam rochas neoproterozoicas, incluindo faixas metavulcanossedimentares distais, sucessões pelito-carbonáticas marginais e bacias molássicas.

3. A Zona Transversal, situada entre os lineamentos Patos e Pernambuco, a qual compreende sequências tectônicas cronologicamente distintas, justapostas por zonas de cisalhamento brasilianas. 


\section{A Zona Transversal}

A Zona Transversal é formada por domínios crustais com características geológicas próprias, estruturados segundo a direção NE-SW. Esses domínios são denominados, de leste para oeste: Rio Capibaribe, Alto Moxotó, Alto Pajeú (inclui o Complexo Riacho Gravatá) e Cachoeirinha, tendo sido individualizados com base em dados geocronológicos (U-Pb em zircão), isotópicos (especialmente Sm-Nd) e geoquímicos (Van Schmus et al., 1995; Ferreira et al., 1998). Dois modelos contrastantes têm sido propostos para explicar a integração desses diferentes domínios durante a orogênese Brasiliana: 1. amalgamação de terrenos ao longo de uma (paleo)margem convergente e dispersão durante a deformação transcorrente brasiliana (Santos, 1996; Brito Neves et al., 2000), ou 2. colagem de blocos no Paleoproterozoico e posterior retrabalhamento neoproterozoico, em um contexto intraplaca (Neves, 2003).

A área de estudo está geologicamente inserida no domínio Alto Pajeú. Esse domínio está limitado a norte pelo Lineamento Patos, a sul por rochas do domínio Alto Moxotó (em contato com o Lineamento Pernambuco), e a oeste com a zona de cisalhamento da Serra do Caboclo (Medeiros, 2004). É constituído dominantemente por associações granito-gnáissicas representadas por plútons eoneoproterozoicos relacionados ao evento Cariris Velhos (c. 950 Ma; Brito Neves et al., 2001), e plútons neoproterozoicos, todos intrusivos em embasamento paleoproterozoico de idade de c. 2,1 Ga (Kozuch, 2003). No setor ocidental desse domínio aflora uma sequência supracrustal representada por metavulcânicas félsicas e máficas intercaladas em unidades metassiliciclásticas (Complexo Riacho Gravatá, de c. 1,0 Ga; Bittar, 1998) (Figura 1). O domínio Alto Moxotó é caracterizado pela intrusão de granitoides (ortognaisses) eoneoproterozoicos e plútons brasilianos em um embasamento constituído dominantemente por ortognaisses bandados, de composição granodiorítica.

O magmatismo cálcio-alcalino a subalcalino neoproterozoico no domínio Alto Pajeú é diacrônico, com idades entre: 1. 650 - 620 Ma (plútons de Tavares, Itapetim e Tabira), 2. 595 - 585 Ma (plútons de Esperança-Pocinhos, Teixeira e Pajeú), e 3. $580 \mathrm{Ma}$ (plúton de Campina Grande) (Brito Neves et al., 2003; Guimarães et al., 2004; Archanjo e Fetter, 2004; Archanjo et al., 2008). Idades-modelos Sm$\mathrm{Nd}$ desse magmatismo se distribuem em dois grupos distintos. Nos plútons de Timbaúba, Teixeira, Itapetim e Tabira os valores TDM situam-se em torno de 1,4 Ga, com $\varepsilon_{\mathrm{Nd}(0)}$ $>-15$, enquanto que nos demais as idades-modelo são mais antigas (c. 1,8 - 2,5 Ga), associadas a valores de $\varepsilon_{\mathrm{Nd}(0)}<-20$ (Archanjo e Fetter, 2004; Guimarães et al., 2004; Brito Neves et al., 2005) (Figura 2). Em ambos os grupos, os dados Sm-Nd sugerem processos de contaminação do magma com a encaixante regional, ou ainda a participação do embasamento como fonte para esses magmas.

\section{$39^{\circ}$}

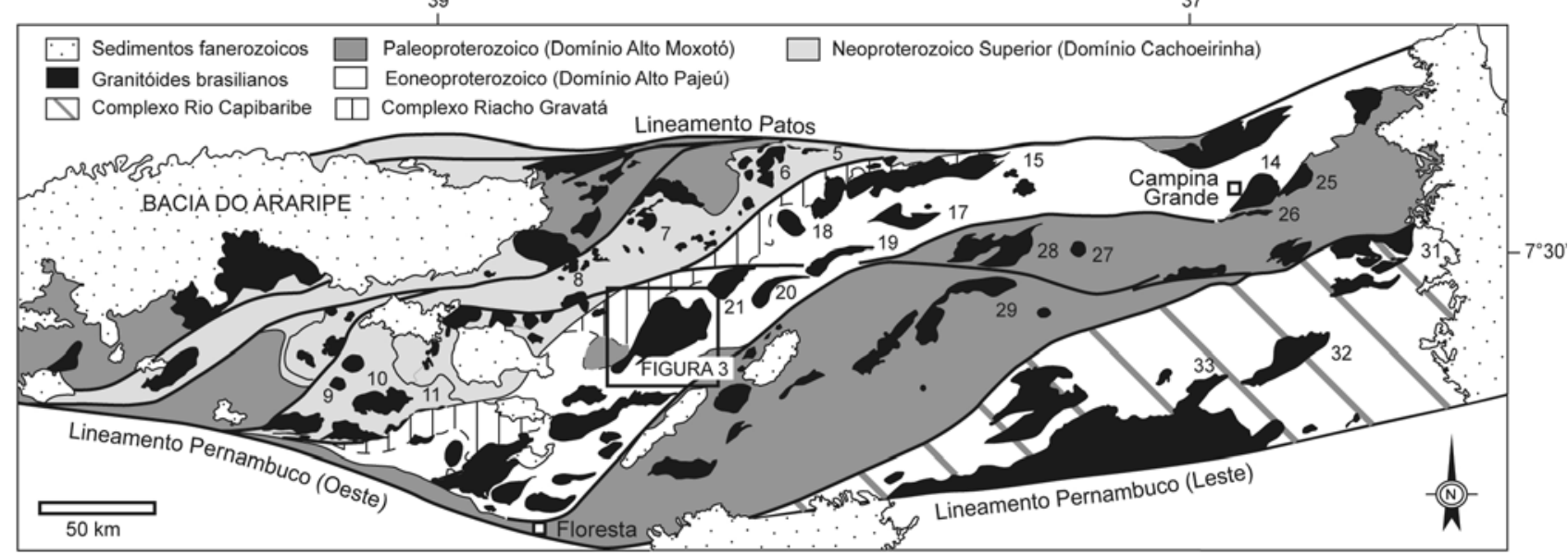

CACHOEIRINHA: 1. Bodocó, 2. Serra da Lagoinha, 3. Monte Horebe, 4. Itaporanga, 5. Catingueira, 6. Emas-Olho D'Água, 7. Pedra Branca, 8. Conceição, 9. Serrita, 10. Salgueiro, 11. Terra Nova.

ALTO PAJEÚ: 12. Esperança, 13. Pocinhos, 14. Campina Grande, 15. Taperoá, 16. Teixeira, 17. Itapetim, 18. Palmeira, 19. Tabira, 20. Solidão, 21. Tavares, 22. Triunfo, 23. Pajeú, 24. Serra do Man.

ALTO MOXOTÓ: 25. Serra Redonda, 26. Queimadas, 27. Uruçu, 28. Serra Branca, 29. Prata, 30. Pereiro-Serra do Velho Zuza RIO CAPIBARIBE: 31. Timbaúba, 32. Bom Jardim, 33. Toritama, 34. Fazenda Nova-Caruaru.

Figura 1. Mapa geológico simplificado da Zona Transversal, com ênfase no magmatismo neoproterozoico e principais zonas de cisalhamento brasilianas. Os números representam os plútons neoproterozoicos reconhecidos e distribuídos em cada um dos domínios desta subprovíncia (modificado de Medeiros, 2004). 


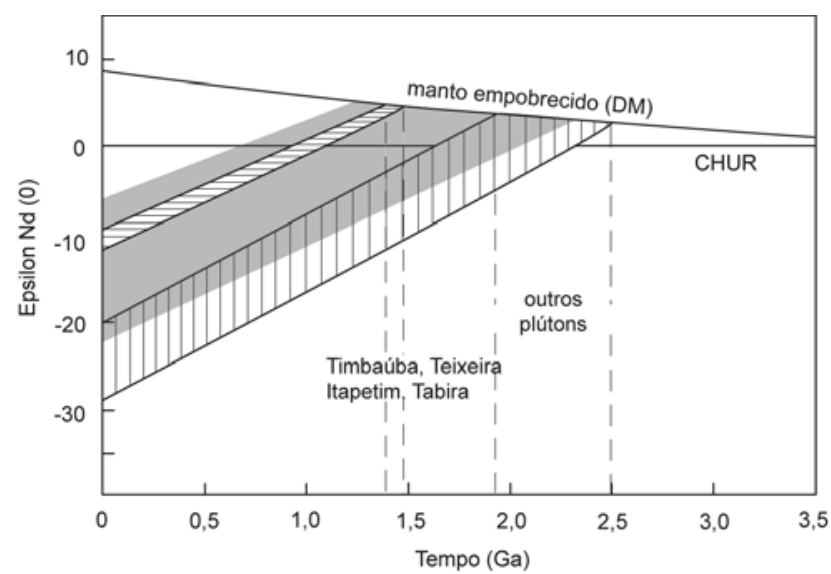

Figura 2. Diagrama $\varepsilon_{\text {Nd }}$ vs. tempo mostrando as curvas de evolução para alguns dos plútons granitoides do domínio Alto Pajeú. Para comparação, a área em cinza corresponde aos valores de $\varepsilon_{\mathrm{Nd}}$ para as rochas do embasamento desses plútons, ortognaisses c. $950 \mathrm{Ma} \mathrm{e}$ c. 2,1 Ga (ver fontes no texto).

\section{Magmatismo ultrapotássico a peralcalino na Zona Transversal}

Os representantes desse magmatismo formam corpos plutônicos e subvulcânicos preferencialmente intrusivos no domínio Alto Pajeú. Composicionalmente, incluem tipos ultrapotássicos (plútons Serra do Man e Triunfo), peralcalinos ultrapotássicos (plútons da Serra do Casé e Serra do Livramento, e os diques de Manaíra), e peralcalinos (plúton de Cacimbas, Serrote das Duas Irmãs e Serrote do Paulo, e os diques de Serrita, Serra do Pico e Terra Nova) (Figura 1) (Sial e Ferreira, 1988; Ferreira e Sial, 1994; Ferreira et al., 1994, 1998; Ferreira et al., 2002; Guimarães et al., 2004). Tipos peralcalinos de ocorrência mais restrita são também cartografados nos domínios Cachoeirinha (diques do Riacho Santo Antônio, Catingueira, Tigre) e Rio Capibaribe (diques Moderna).

A associação mineralógica típica nessas rochas é bastante homogênea, consistindo basicamente de microclina pertítica e egirina-augita, com anfibólio sódico (riebeckita-richterita-winchita) subordinado, por vezes substituindo parcialmente piroxênio (Ferreira et al., 1994, 1998). Especificamente no sienito de Triunfo, Ferreira e colaboradores descrevem a ocorrência de piroxenitos como diques sinplutônicos ou enclaves coexistindo em equilíbrio químico com o magma sienítico, sugerindo imiscibilidade de líquidos. Idade $\mathrm{Rb}-\mathrm{Sr}$ (rocha total) obtida para esse plúton é de $583 \pm 12 \mathrm{Ma}$, com razão ${ }^{87} \mathrm{Sr} /{ }^{86} \mathrm{Sr}$ inicial de 0,710 . Idades modelo Sm-Nd agrupam-se entre 2,0 e 2,5 Ga, com $\varepsilon_{\mathrm{Nd}(0)}$ fortemente negativo (Figura 2).

\section{O ENXAME DE DIQUES DE MANAÍRA- PRINCESA ISABEL}

O enxame de diques de Manaíra aflora em uma área de aproximadamente $60 \mathrm{~km}^{2}$, limitada a norte pelos milonitos verticais da zona de cisalhamento Juru-Belém e a sul-leste pelas cidades de Manaíra, Princesa Isabel e Tavares (PB) (Figura 3). Alguns diques também são mapeados próximos à cidade de Serra Talhada (PE), mas desaparecem no polígono circunscrito por esta cidade e aquelas de Triunfo e Flores, também em Pernambuco.

Sua ocorrência é definida pelo alinhamento (semi)contínuo de altos topográficos segundo a direção NE-SW, com variações locais para N-S na região a sul-sudoeste de Manaíra. Em campo, os diques não estão associados a cristas do relevo regional. Em Tavares e Princesa Isabel, por exemplo, os diques estão arrasados e destacam-se da encaixante granítica (os plútons homônimos) pela cor mais escura (Figura 4A). Relações de intrusão com o sienito de Triunfo não são diretamente observadas. Aparentemente os diques não afetam esse plúton que, por sua vez, é intrusivo no granito porfirítico de Princesa Isabel. Por essas relações e pelas semelhanças mineralógicas, o sienito de Triunfo e o enxame de diques de Manaíra têm sido considerados um evento magmático único (Sial, 1986; Sial e Ferreira, 1988).

Os diques constituem rochas maciças normalmente com granulação fina e contatos subverticais bem definidos com a encaixante. Diques com textura porfirítica fina são encontrados em Tavares e a norte de Princesa Isabel. As larguras são variáveis, desde uma dezena de centímetros até algumas dezenas de metros, sendo a média entre 1 e $3 \mathrm{~m}$. O comprimento estimado por observação direta e cartografia digital é de algumas dezenas de metros a alguns quilômetros. Ocorrem cortando tanto os granitos porfiríticos de Princesa Isabel e Tavares e suas estruturas magmáticas, bem como a foliação metamórfica de baixo grau nos metassedimentos do Complexo Riacho Gravatá (Figura 4B). No contato com essas encaixantes os diques frequentemente desenvolvem uma margem resfriada de alguns centímetros de largura, indicando colocação em nível crustal raso (Figura 4C).

\section{GEOCRONOLOGIA}

A datação U-Pb foi feita em zircões do dique DKMN02, que aflora próximo à cidade de Manaíra. Sua escolha deve-se à sua significativa representatividade petrográfica (textura/mineralogia/quimismo) com respeito ao enxame (ver itens seguintes). Foram selecionados cerca de 23 grãos para análise pontual na microssonda iônica SHRIMP II da Research School of Earth Sciences, Australian National University. Detalhes sobre procedimentos analíticos estão sumarizados no Apêndice A. 
$38^{\circ} 30$

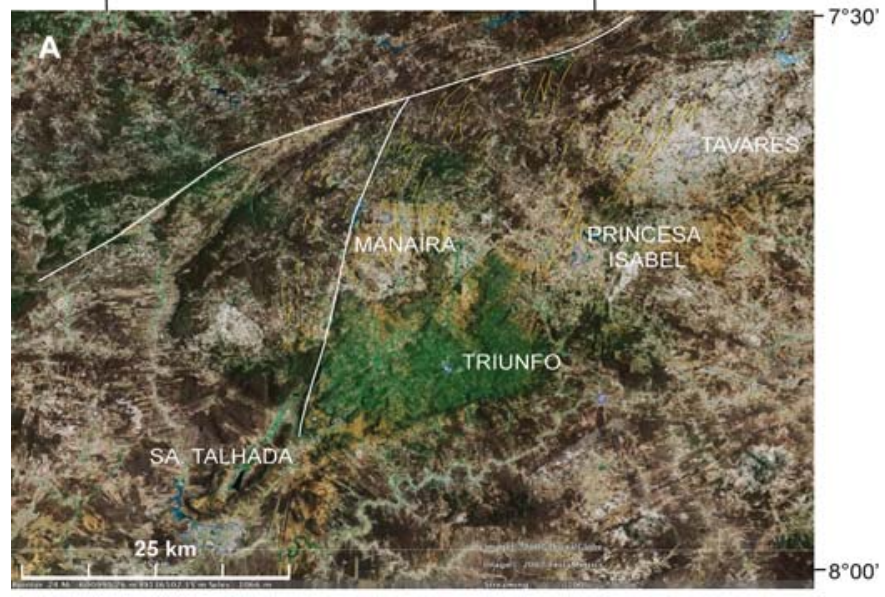

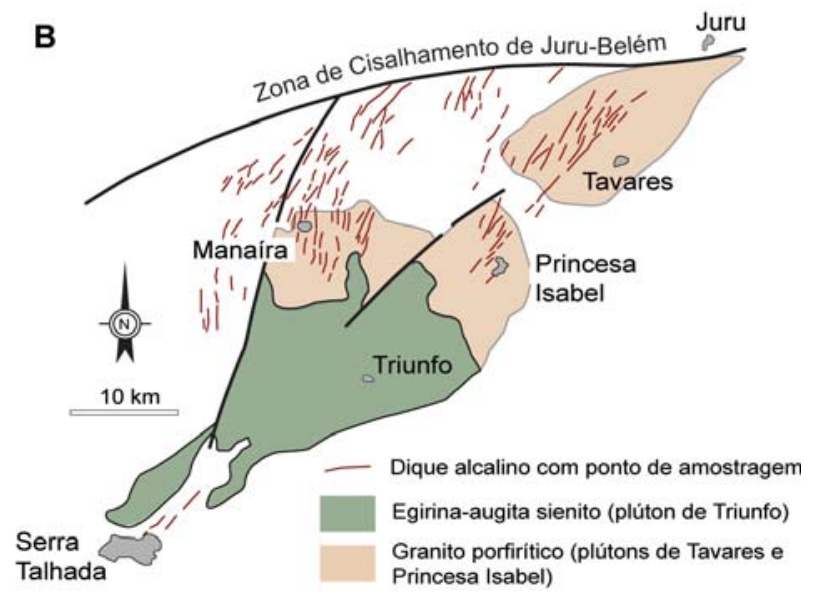

Figura 3. A. Imagem de satélite LANDSAT mostrando o contraste espectral entre o sienito de Triunfo (verde), os plútons de Princesa Isabel e Tavares (ambos em branco) e os ortognaisses regionais (marrom). Em amarelo foram destacados os diques estudados. B. Mapa esquemático ilustrando as relações espaciais entre os diques e suas encaixantes, bem como sua distribuição com respeito à zona de cisalhamento Juru-Belém.
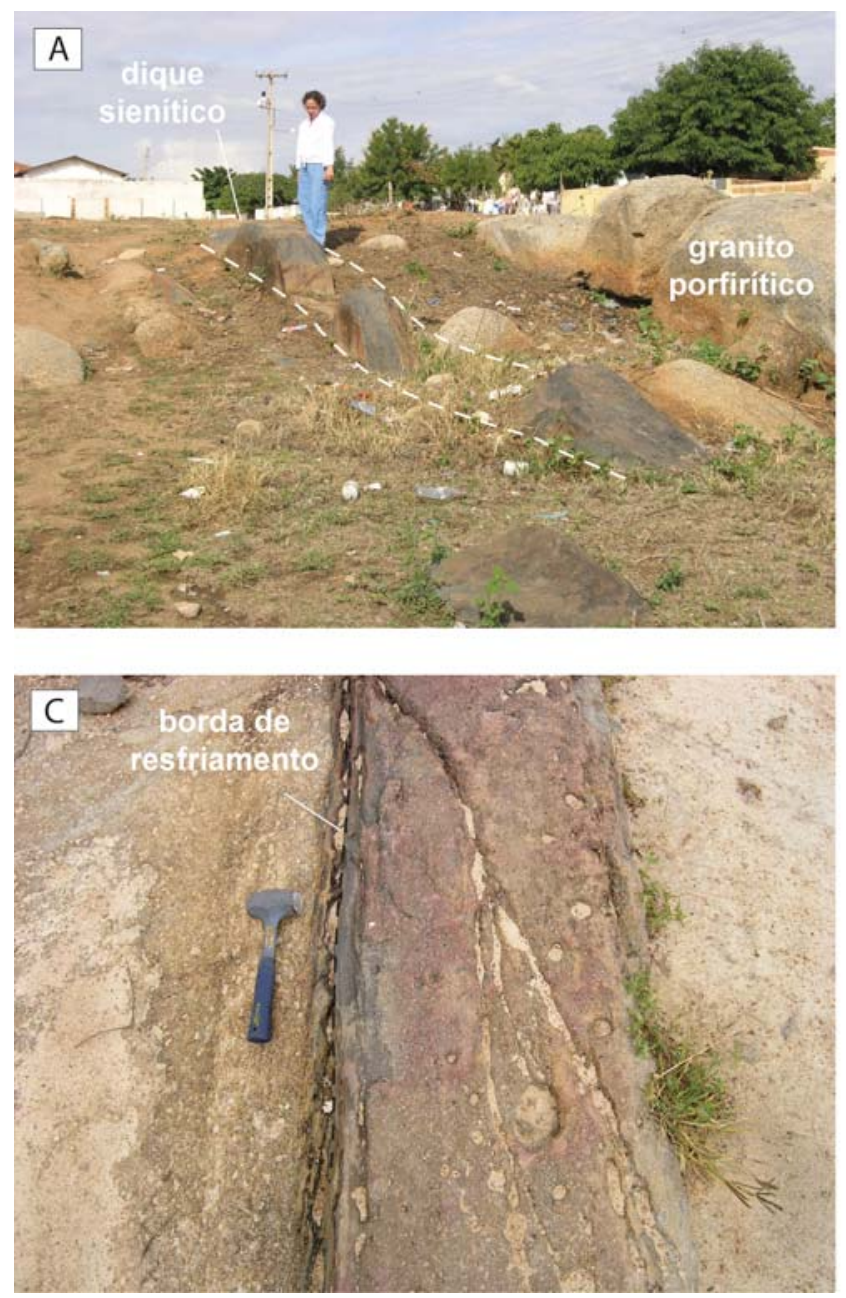

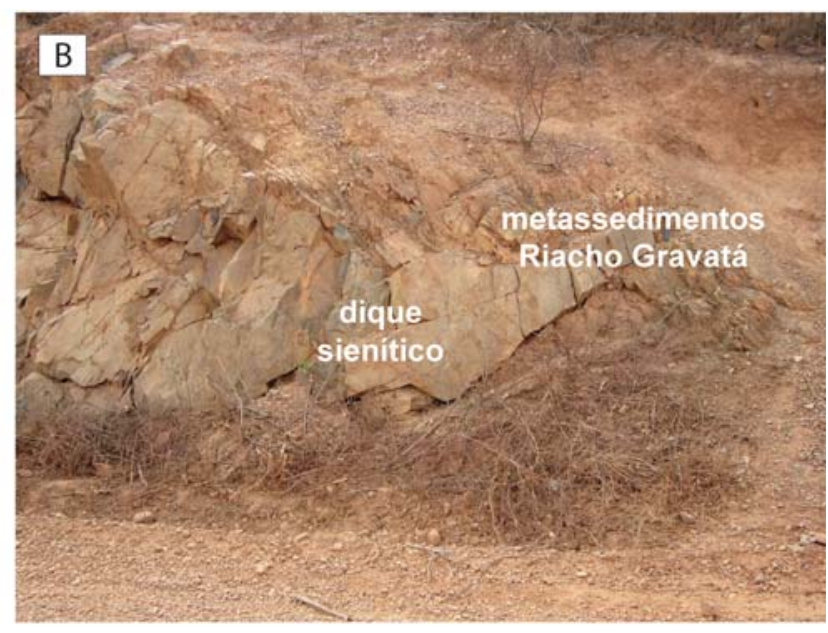

Figura 4. Diques de sienito de direção NE-SW intrusivos em: A. granito porfirítico de Princesa Isabel; B. metassedimentos do Complexo Riacho Gravatá; C. dique com bordas de resfriamento desenvolvidas ao longo do contato com encaixante regional. 


\section{Geocronologia U-Pb}

A análise da população de zircões do dique DKMN-02 mostrou ampla diversidade temporal, com grãos de idades paleo-, meso- e neoproterozoica (Figuras 5A e 5B; Tabela 1). A população mais antiga inclui zircões com idades ${ }^{207} \mathrm{~Pb} /{ }^{206} \mathrm{~Pb}$ entre $2,39-1,86 \mathrm{Ga}$, a grande maioria com algum grau de discordância. Dois grãos definem um pequeno grupo com idades c. 940 - $920 \mathrm{Ma}$, enquanto um terceiro grupo de 4 grãos forneceu idades em c. $600 \mathrm{Ma}$. Por fim, duas análises fortemente discordantes plotam próximas a 540 Ma.

A representatividade individual de cada grupo é baixa. Grãos paleoproterozoicos certamente foram herdados quando da ascensão dos diques, uma vez que as relações de campo mostram claramente a intrusão tardia dos diques com respeito às estruturas dúcteis, neoproterozoicas, que afetam o embasamento regional. Embora não exatamente aflorando nas proximidades da área de ocorrência desses diques, os ortognaisses Cariris Velhos podem ter sido a fonte potencial dos zircões eoneoproterozoicos (c. 950 Ma). A exclusão desses dois grupos mais antigos leva-nos a considerar os dois grupos restantes, de idades neoproterozoica e cambriana, como aqueles que mais provavelmente representariam a idade desse magmatismo.
O grupo de idades cambrianas é representado, na verdade, por apenas duas análises (spots \#3.1 e \#5.1) com idades ${ }^{206} \mathrm{~Pb} /{ }^{238} \mathrm{~Pb}$ c. $540 \mathrm{Ma}$, fortemente discordantes, com erros elevados para as razões ${ }^{207} \mathrm{~Pb} /{ }^{235} \mathrm{~Pb}$. A qualidade analítica do dado fornecido pelo grão/spot \#5.1 é ainda prejudicada face ao alto conteúdo de $\mathrm{Pb}$ comum medido. Essas características sugerem que os dois grãos possam representar zircões mais antigos, parcialmente afetados por um evento termal posterior à sua formação. Por sua vez, o grupo de idade neoproterozoica é representado por quatro análises (spots \#1.1, \#14.1, \#18.1 e \#19.1) em torno de 600 Ma. Dessas, apenas o grão 14.1 é fortemente discordante, enquanto o grão \#18.1 tem idade ${ }^{206} \mathrm{~Pb} /{ }^{238} \mathrm{~Pb}$ discretamente mais elevada que o conjunto dos demais três grãos. Todavia, a excelente qualidade analítica do dado fornecido pelo grão/spot \#19.1, concordante em ${ }^{206} \mathrm{~Pb} /{ }^{238} \mathrm{U}$ de $603,6 \pm 3,9$ Ma, valida a informação cronológica do conjunto. Apesar de estatisticamente pouco representativa, a idade neoproterozoica desse conjunto parece ser a mais provável para o enxame de diques de Manaíra.

\section{PETROGRAFIA E QUÍMICA MINERAL}

Diferenças com respeito à composição química da assembleia máfica e padrões texturais, levaram à definição de

Tabela 1. Dados U-Pb SHRIMP para zircões da amostra DKMN-02. Erros são 1-sigma; $\mathrm{Pb}_{\mathrm{c}}$ e $\mathrm{Pb}$ * indicam as frações de $\mathrm{Pb}$ comum e radiogênico, respectivamente. O erro na calibração do padrão foi 0,23\% (não incluído nos erros individuais, mas necessário na comparação entre dados de diferentes mounts). (1) $\mathrm{Pb}$ comum corrigido usando os valores de ${ }^{204} \mathrm{~Pb}$ medido.

\begin{tabular}{|c|c|c|c|c|c|c|c|c|c|c|c|c|c|c|c|c|}
\hline Spot & $\begin{array}{c}\% \\
{ }^{206} \text { Pbc }\end{array}$ & $\begin{array}{c}\text { U } \\
\text { ppm }\end{array}$ & $\begin{array}{c}\text { Th } \\
\text { ppm }\end{array}$ & $\begin{array}{l}{ }^{206} \mathbf{P b} \text { * } \\
\text { ppm }\end{array}$ & $\begin{array}{c}{ }^{206} \mathrm{~Pb} /{ }^{238} \mathrm{U} \\
\text { (1) }\end{array}$ & & $\begin{array}{c}{ }^{207} \mathrm{~Pb} /{ }^{206} \mathrm{P} \\
\text { b } \\
(1)\end{array}$ & & $\begin{array}{c}\% \\
\text { Disc }\end{array}$ & $\begin{array}{c}{ }^{207} \mathbf{P b} \mathbf{b}^{* 206} \mathbf{P} \\
\mathbf{b}^{*} \\
\text { (1) }\end{array}$ & $\pm \%$ & $\begin{array}{c}{ }^{207} \mathbf{P b}{ }^{*}{ }^{2} \\
\mathbf{U} \\
(1)\end{array}$ & $\pm \%$ & $\begin{array}{c}{ }^{206} \mathrm{~Pb}^{\star / 238} \\
\mathrm{U} \\
(1)\end{array}$ & $\pm \%$ & corr \\
\hline 1,1 & 1,85 & 320 & 184 & 27,4 & 600,9 & $\pm 4,6$ & 588 & \pm 83 & -2 & 0,0596 & 3,8 & 0,803 & 3,9 & 0,0977 & 0,8 & 0,21 \\
\hline 2,1 & 3,11 & 374 & 110 & 101 & 1710 & \pm 15 & 1978 & \pm 59 & 14 & 0,1215 & 3,3 & 5,09 & 3,5 & 0,3038 & 1 & 0,3 \\
\hline 3,1 & 3,37 & 178 & 82 & 14 & 545,7 & $\pm 5,3$ & 693 & \pm 160 & 21 & 0,0626 & 7,5 & 0,762 & 7,5 & 0,0883 & 1 & 0,13 \\
\hline 4,1 & 9,32 & 1222 & 333 & 179 & 923 & \pm 11 & 890 & \pm 370 & -4 & 0,069 & 18 & 1,46 & 18 & 0,1539 & 1,3 & 0,07 \\
\hline 5,1 & 14,09 & 265 & 133 & 23,1 & 537,2 & $\pm 6,9$ & 621 & \pm 180 & 13 & 0,0605 & 8,4 & 0,725 & 8,5 & 0,0869 & 1,3 & 0,16 \\
\hline 6,1 & 0,07 & 358 & 184 & 117 & 2086 & \pm 14 & 2178 & $\pm 5,6$ & 4 & 0,1361 & 0,3 & 7,168 & 0,9 & 0,382 & 0,8 & 0,93 \\
\hline 7,1 & 0,08 & 373 & 67 & 105 & 1825 & \pm 19 & 1858 & \pm 14 & 2 & ,1136 & 0,8 & 5,126 & 1,4 & 0,3273 & 1,2 & 0,85 \\
\hline 8,1 & 0,19 & 173 & 76 & 60 & 2176 & \pm 15 & 2228 & \pm 15 & 2 & 0,1401 & 0,9 & 7,756 & 1,2 & 0,4016 & 0,8 & 0,68 \\
\hline 10,1 & 0,11 & 139 & 71 & 48,4 & 2187 & \pm 16 & 2205 & $\pm 7,9$ & 1 & 0,1382 & 0,5 & 7,695 & 0,9 & 0,4038 & 0,9 & 0,88 \\
\hline 11,1 & 0,29 & 174 & 77 & 23,6 & 942,7 & $\pm 7,1$ & 966 & \pm 24 & 2 & 0,0713 & 1,2 & 1,548 & 1,4 & 0,1575 & 0,8 & 0,57 \\
\hline 12,1 & 0,1 & 278 & 65 & 76,4 & 1788 & \pm 11 & 1863 & $\pm 7,8$ & 4 & 0,1139 & 0,4 & 5,021 & 0,9 & 0,3196 & 0,7 & 0,86 \\
\hline 12,2 & 3,02 & 310 & 31 & 94 & 1888 & \pm 14 & 2079 & \pm 58 & 9 & 0,1286 & 3,3 & 6,03 & 3,4 & 0,3404 & 0,9 & 0,25 \\
\hline 14,1 & - & 299 & 183 & 25,2 & 603,6 & $\pm 4,3$ & 711 & \pm 19 & 15 & 0,0631 & 0,9 & 0,854 & 1,2 & 0,0982 & 0,8 & 0,64 \\
\hline 16,1 & 0,1 & 136 & 35 & 51,2 & 2336 & \pm 17 & 2393 & \pm 51 & 2 & 0,1542 & 3 & 9,29 & 3,1 & 0,4368 & 0,9 & 0,28 \\
\hline 17,1 & 0,19 & 212 & 60 & 66 & 1989 & \pm 22 & 1982 & \pm 17 & 0 & 0,1217 & 0,9 & 6,066 & 1,6 & 0,3614 & 1,3 & 0,79 \\
\hline 18,1 & 1,32 & 758 & 72 & 66,8 & 621,4 & \pm 4 & 590 & \pm 37 & -5 & 0,0596 & 1,7 & 0,832 & 1,8 & 0,1012 & 0,7 & 0,37 \\
\hline 19,1 & 0,5 & 861 & 194 & 73 & 603,6 & $\pm 3,9$ & 603 & \pm 35 & 0 & 0,0599 & 1,6 & 0,812 & 1,8 & 0,09816 & 0,7 & 0,39 \\
\hline 23,1 & 1,59 & 472 & 286 & 143 & 1914 & \pm 12 & 1971 & \pm 16 & 3 & 0,1211 & 0,9 & 5,767 & 1,1 & 0,3456 & 0,7 & 0,63 \\
\hline 23,2 & 0,32 & 41 & 13 & 15,7 & 2353 & \pm 57 & 2264 & \pm 43 & -4 & 0,1431 & 2,5 & 8,69 & 3,8 & 0,441 & 2,9 & 0,76 \\
\hline
\end{tabular}



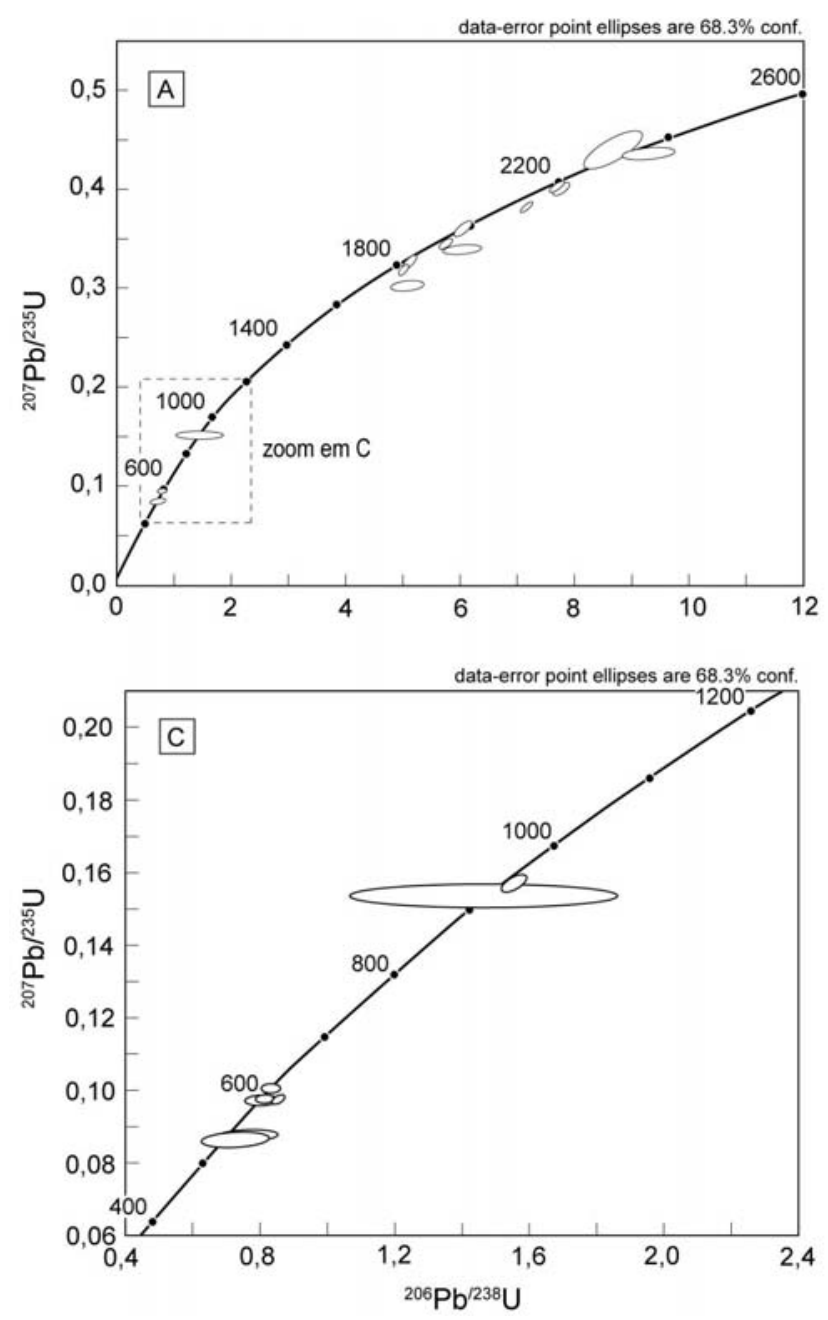

quatro subenxames: 1. Manaíra, 2. Princesa Isabel, 3. Tavares e 4. Serra Talhada, sendo suas áreas de ocorrência o entorno das cidades homônimas. Comentários sobre o procedimento para obtenção dos dados de química mineral são sumarizados no Apêndice B; os resultados estão apresentados nas Tabelas 2A a 2D.

\section{Aspectos petrográficos}

Macroscopicamente os diques são homogêneos, não deformados e sem alterações mineralógicas visíveis. Consistem em rochas de cor cinza, com textura fanerítica fina. Em geral os diques dos subenxames Manaíra e Princesa Isabel têm granulação, mineralogia e texturas similares, em parte também compartilhados pelos diques do subenxame Tavares. A assembleia mineralógica é representada por Kfeldspato + piroxênio \pm anfibólio, e apatita, titanita e zircão como minerais acessórios. Já os diques do subenxame Ser-

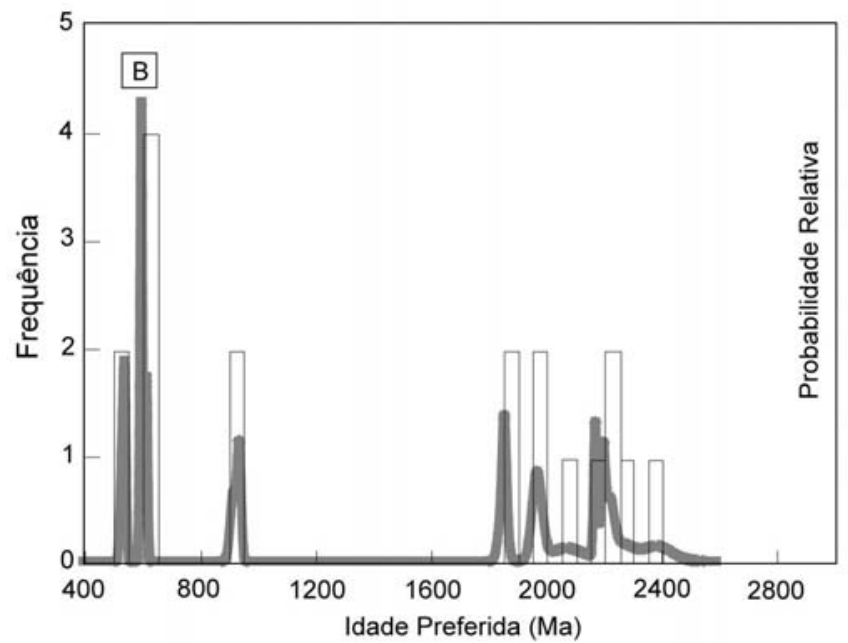

Figura 5. A. Diagrama Concórdia Wetherhill ilustrando a distribuição das populações de zircões analisados do dique DKMN-02. B. Respectivo histograma de frequência dos dados analíticos. C. Zoom da parte inferior do diagrama, com destaque para as populações mais jovens.

ra Talhada apresentam cristais de K-feldspatos fortemente sericitizados, sendo biotita a única fase mineral máfica.

Os resultados modais mostram a dominância de K-feldspato como fase mineral principal ( 59 - $82 \%$ em Tavares e 80 - 95\% nos demais subenxames), subordinadamente acompanhado pelas fases máficas piroxênio, anfibólio e biotita. Considerando a ausência de quartzo e plagioclásio modais em todas as amostras, K-feldspato representaria 100\% do total de félsicos no diagrama Q-A-P de Streckeisen (1976), sendo os diques petrograficamente classificados como álcali-feldspato sienitos.

\section{Subenxame Manaíra}

Ao microscópio os diques desse subenxame mostram textura inequigranular, hipidiomórfica a xenomórfica, com notável variação granulométrica. A assembleia mineralógica é dominada por K-feldspato + piroxênio \pm anfibólio. 


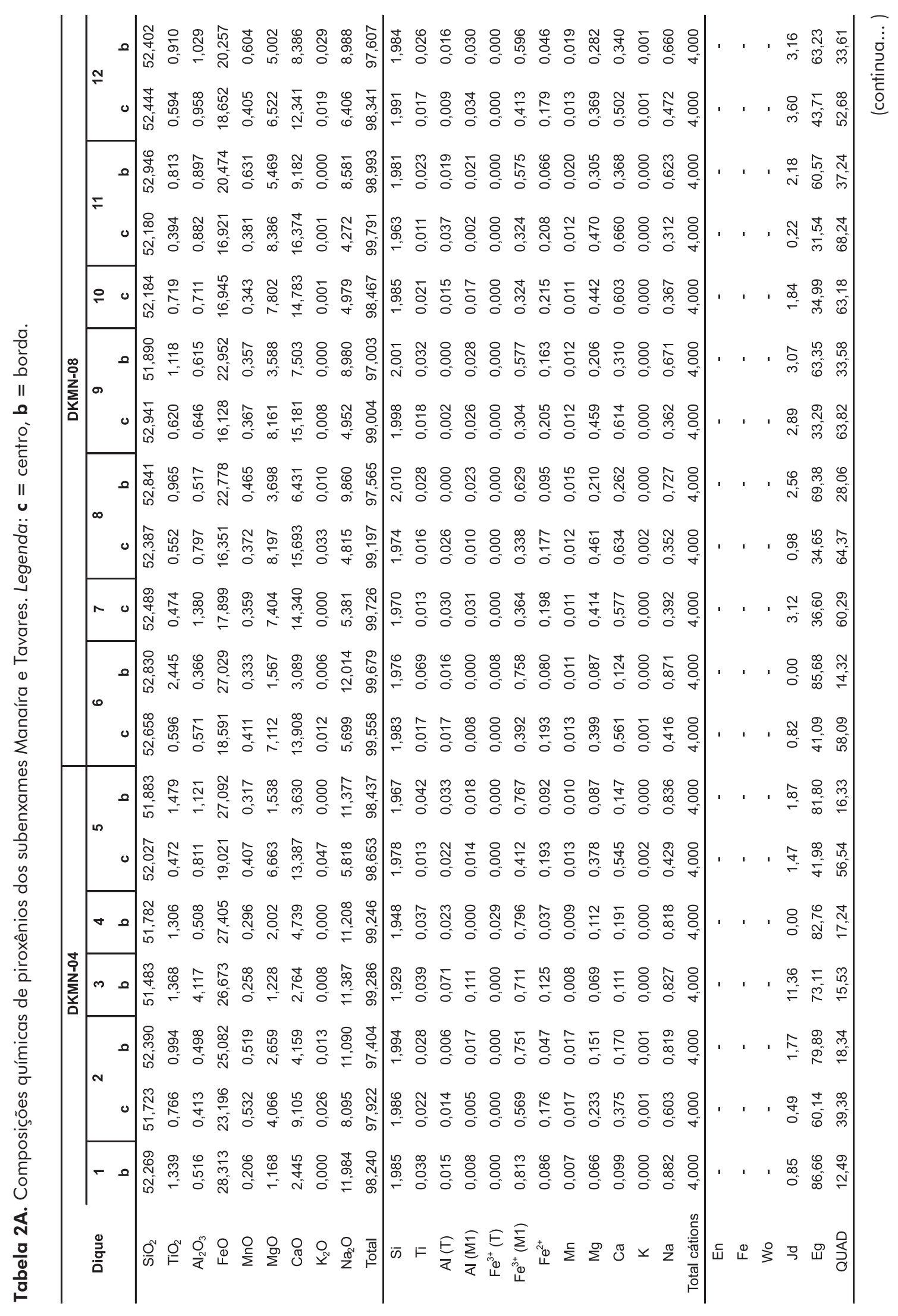




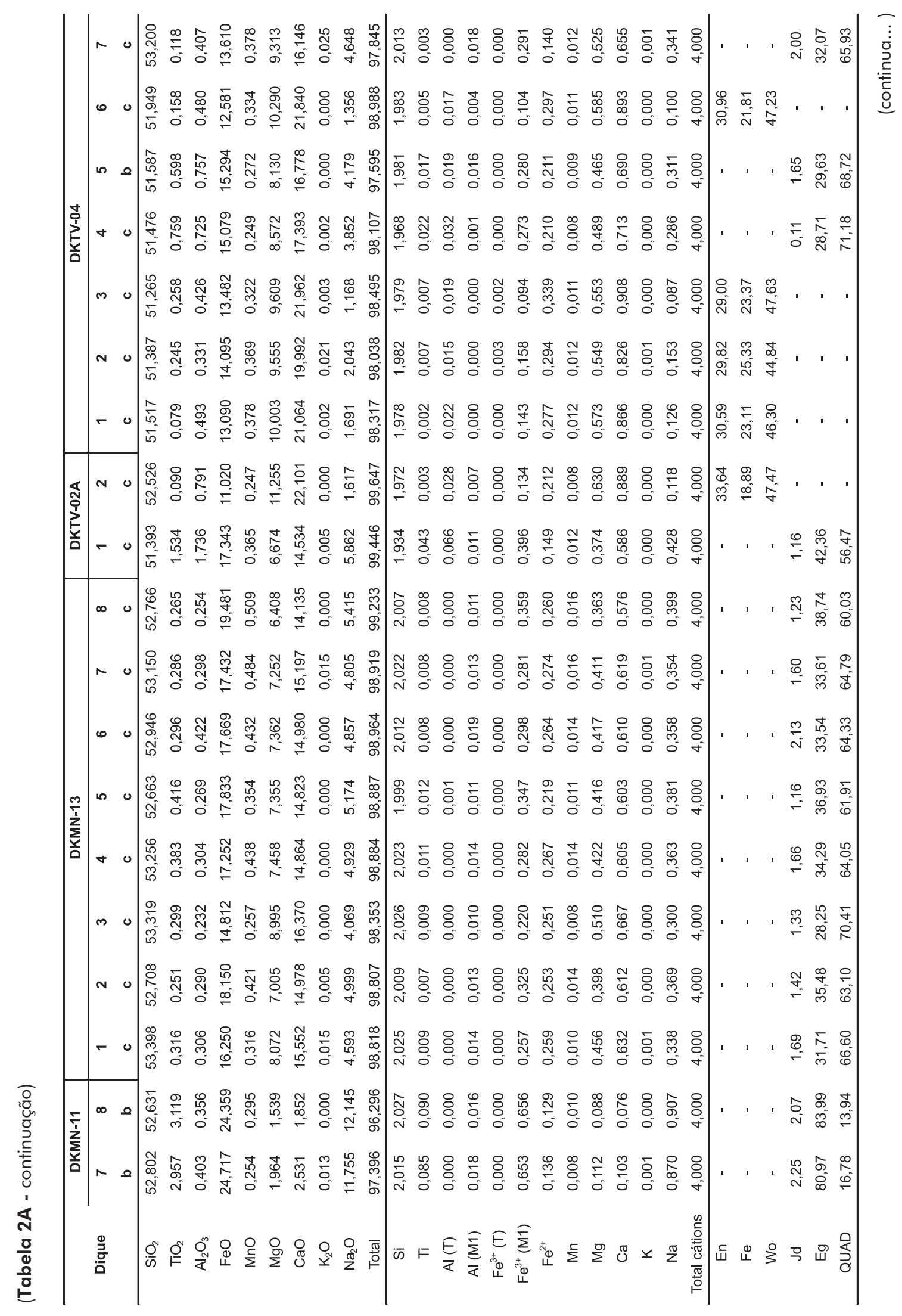




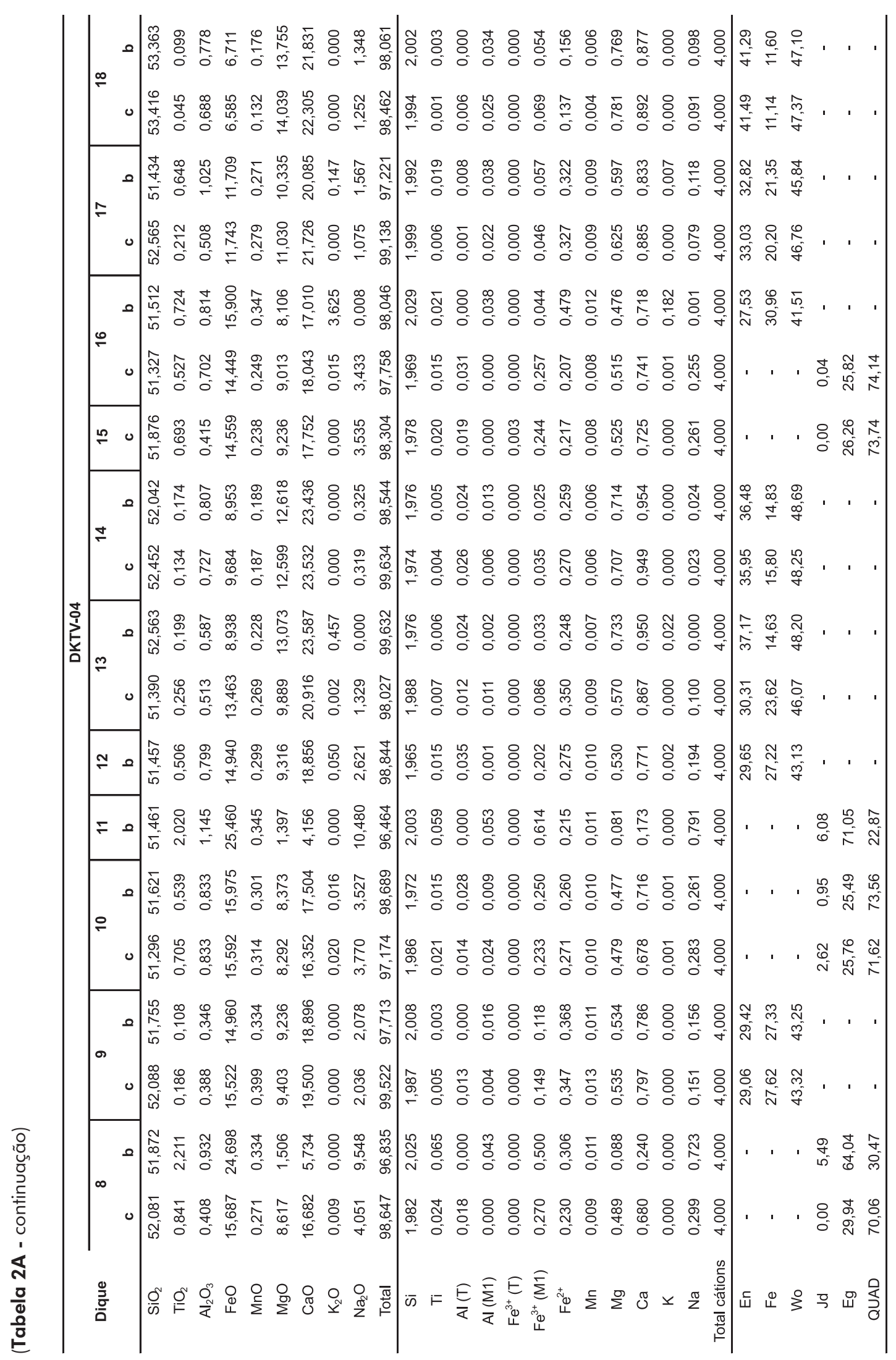




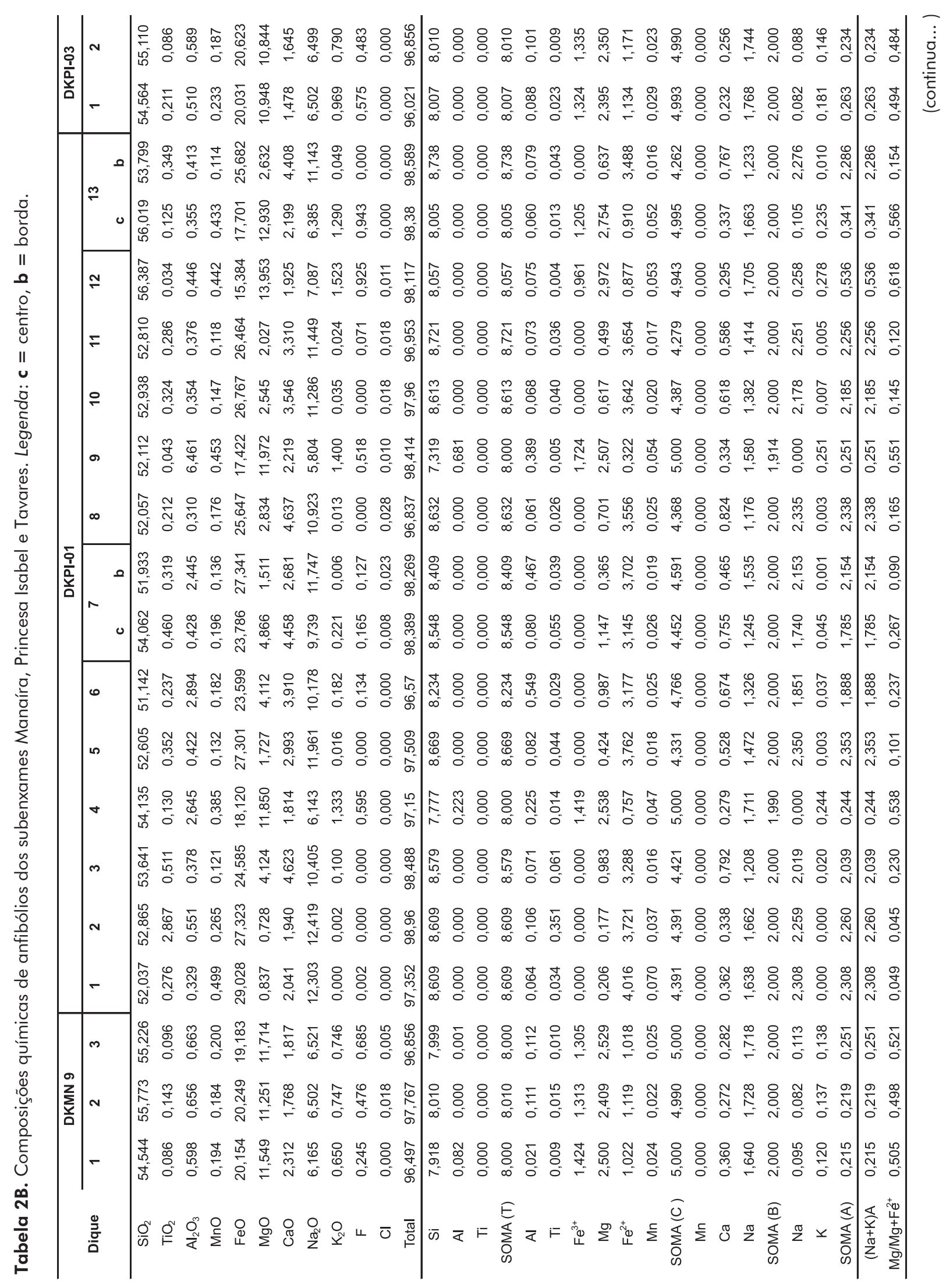




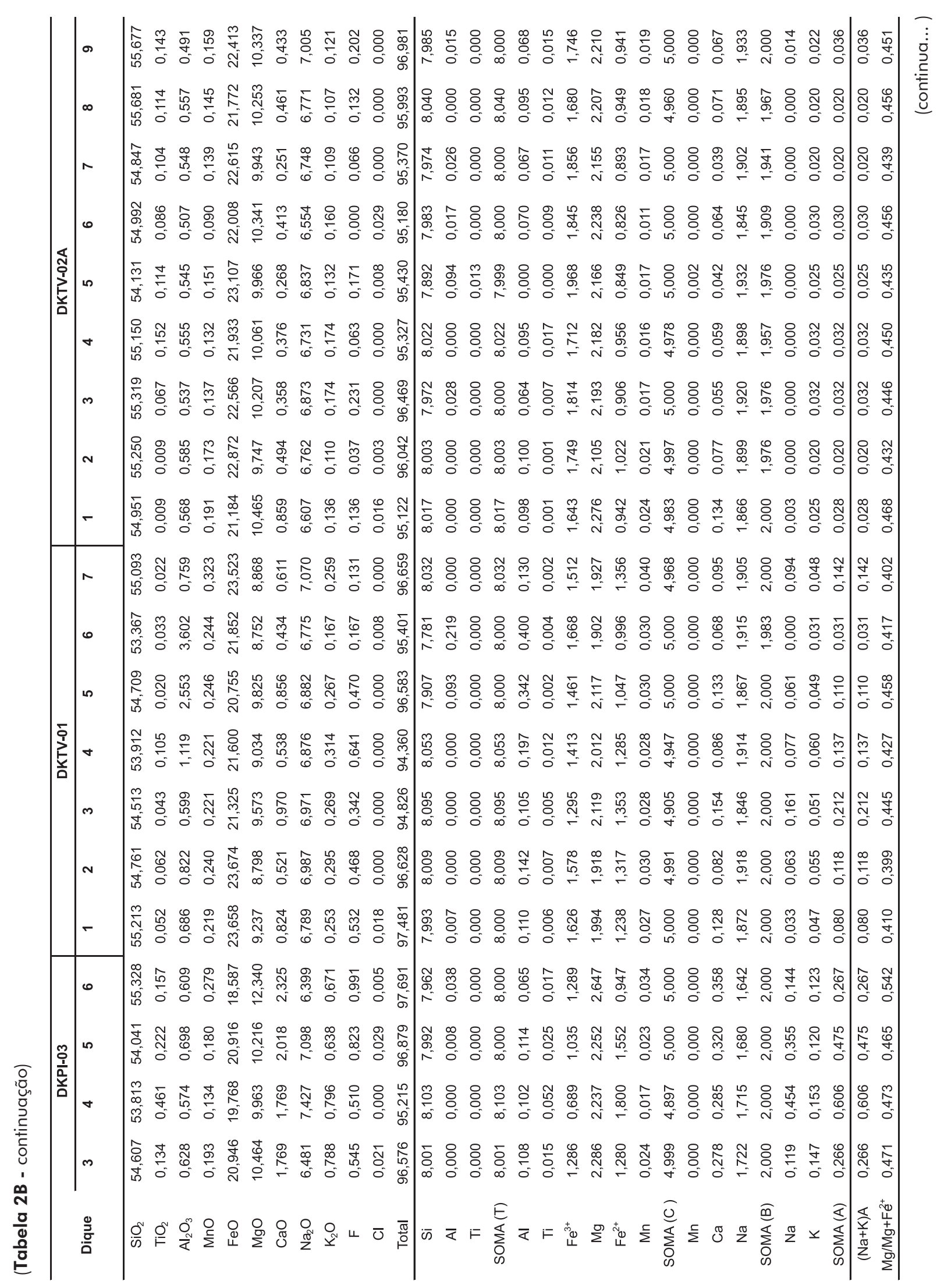




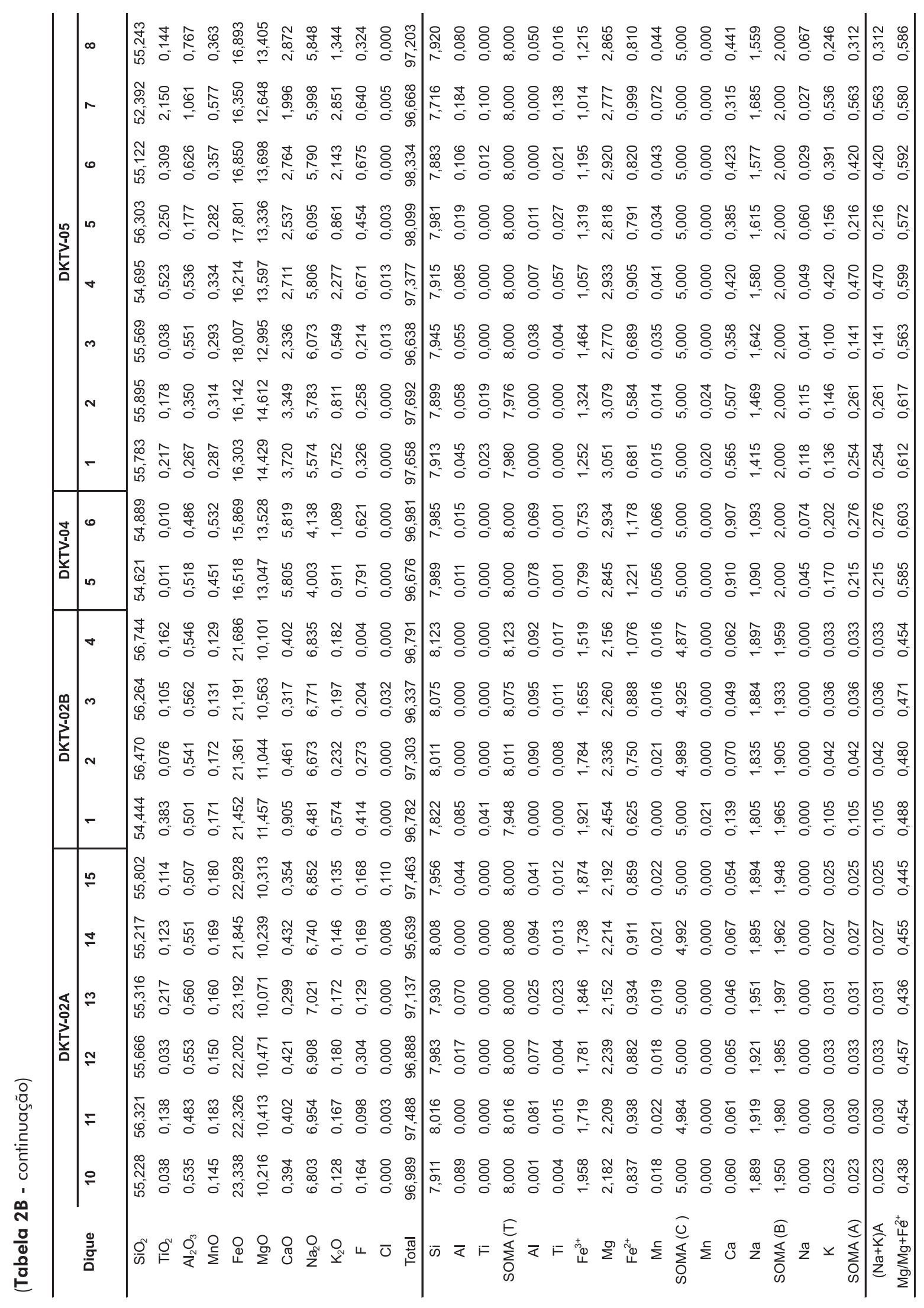


Tabela 2C. Composições químicas de feldspatos do subenxame Tavares. Legenda: $\mathbf{c}=$ centro, $\mathbf{b}=$ borda.

\begin{tabular}{|c|c|c|c|c|c|c|c|c|c|c|}
\hline \multirow{3}{*}{ Dique } & \multicolumn{10}{|c|}{ DKMN 9} \\
\hline & \multicolumn{2}{|c|}{1} & \multicolumn{2}{|c|}{2} & \multicolumn{2}{|c|}{3} & \multicolumn{2}{|c|}{4} & \multicolumn{2}{|c|}{5} \\
\hline & c & b & c & b & c & b & c & b & c & b \\
\hline $\mathrm{SiO}_{2}$ & 64,08 & 66,57 & 66,40 & 66,11 & 65,97 & 66,75 & 66,65 & 65,53 & 65,98 & 66,57 \\
\hline $\mathrm{TiO}_{2}$ & 0,08 & 0,00 & 0,00 & 0,04 & 0,00 & 0,08 & 0,09 & 0,04 & 0,04 & 0,04 \\
\hline $\mathrm{Al}_{2} \mathrm{O}_{3}$ & 18,52 & 19,27 & 19,31 & 19,66 & 19,03 & 19,02 & 19,57 & 19,86 & 19,43 & 19,27 \\
\hline $\mathrm{Fe}_{2} \mathrm{O}_{3}$ & 0,48 & 0,13 & 0,14 & 0,13 & 0,12 & 0,06 & 0,12 & 0,08 & 0,13 & 0,13 \\
\hline $\mathrm{CaO}$ & 0,84 & 0,69 & 0,34 & 0,77 & 0,26 & 0,34 & 0,68 & 0,67 & 0,45 & 0,42 \\
\hline $\mathrm{BaO}$ & 0,14 & 0,23 & 0,15 & 0,11 & 0,33 & 0,36 & 0,27 & 0,76 & 0,50 & 0,28 \\
\hline $\mathrm{Na}_{2} \mathrm{O}$ & 2,92 & 7,02 & 6,40 & 6,92 & 6,06 & 6,28 & 7,78 & 6,71 & 6,10 & 6,94 \\
\hline $\mathrm{K}_{2} \mathrm{O}$ & 12,11 & 6,32 & 7,45 & 6,38 & 7,90 & 7,42 & 5,46 & 6,41 & 7,54 & 6,64 \\
\hline Total & 99,17 & 100,21 & 100,19 & 100,12 & 99,67 & 99,28 & 100,63 & 100,05 & 100,16 & 100,28 \\
\hline $\mathrm{Si}$ & 11,85 & 11,90 & 11,91 & 11,83 & 11,92 & 11,91 & 11,85 & 11,79 & 11,87 & 11,91 \\
\hline $\mathrm{Al}$ & 4,10 & 4,06 & 4,08 & 4,14 & 4,05 & 4,06 & 4,10 & 4,21 & 4,12 & 4,06 \\
\hline $\mathrm{Fe}^{3+}$ & 0,02 & 0,02 & 0,02 & 0,02 & 0,02 & 0,01 & 0,02 & 0,01 & 0,02 & 0,02 \\
\hline $\mathrm{Ti}$ & 0,00 & 0,00 & 0,00 & 0,01 & 0,00 & 0,01 & 0,01 & 0,01 & 0,01 & 0,01 \\
\hline $\operatorname{SOMA}(\mathrm{T})$ & 15,98 & 15,97 & 16,00 & 16,00 & 15,99 & 15,99 & 15,97 & 16,01 & 16,00 & 15,99 \\
\hline $\mathrm{Ca}$ & 0,02 & 0,02 & 0,01 & 0,01 & 0,02 & 0,03 & 0,02 & 0,05 & 0,04 & 0,02 \\
\hline $\mathrm{Ba}$ & 0,12 & 0,13 & 0,06 & 0,15 & 0,05 & 0,07 & 0,13 & 0,13 & 0,09 & 0,08 \\
\hline $\mathrm{Na}$ & 1,96 & 2,43 & 2,23 & 2,40 & 2,12 & 2,21 & 2,68 & 2,34 & 2,13 & 2,41 \\
\hline $\mathrm{K}$ & 1,92 & 1,44 & 1,70 & 1,46 & 1,82 & 1,72 & 1,24 & 1,47 & 1,73 & 1,52 \\
\hline SOMA (M) & 4,02 & 4,02 & 4,00 & 4,01 & 4,02 & 4,01 & 4,07 & 3,99 & 3,98 & 4,02 \\
\hline Total cátions & 20,01 & 19,99 & 20,01 & 20,01 & 20,01 & 20,00 & 20,04 & 20,00 & 19,98 & 20,01 \\
\hline$A b$ & 48,70 & 60,50 & 55,60 & 59,80 & 52,80 & 55,00 & 65,90 & 58,60 & 53,50 & 59,80 \\
\hline An & 2,90 & 3,30 & 1,60 & 1,20 & 1,20 & 1,60 & 3,20 & 3,30 & 2,20 & 2,00 \\
\hline Or & 47,80 & 35,80 & 42,50 & 45,30 & 45,30 & 42,80 & 30,40 & 36,80 & 43,50 & 37,70 \\
\hline
\end{tabular}

O K-feldspato é microclina. Ocorre como cristais de dimensões variadas, entre 0,1 e $1 \mathrm{~mm}$, e morfologia subédrica a anédrica. É comum observar a macla albita-periclina em grade, com pertitas tipo string e stringlets presentes apenas nos cristais maiores.

O piroxênio ocorre como cristais subédricos a anédricos, ora dispersos e em contato direto com feldspatos, ora formando pequenos agregados monominerálicos, com pleocroísmo variando de verde esmeralda a verde amarelado. Por vezes pode mostrar leve corrosão/absorção magmática nas bordas. Quando observada a zonação é concêntrica (Figura 6A), refletindo as variações composicionais ditadas pela troca preferencial entre $\mathrm{Na}$ e $\mathrm{Ca}\left[\mathrm{NaFe}^{3+} \Leftrightarrow \mathrm{Ca}\left(\mathrm{Mg}, \mathrm{Fe}^{2+}\right)\right]$ no sítio M2. Nesses casos, os centros dos cristais são dominantemente menos sódicos (egirina-augita) em relação às bordas (egirina) (Figura 7A). O anfibólio aparece em proporção significativamente menor em relação ao piroxênio. São cristais subédricos a anédricos, com forte pleocroísmo verde azulado (Figura 6B). Suas composições são sódicas, ricas em $\mathrm{Mg}\left[\mathrm{Mg} /\left(\mathrm{Mg}+\mathrm{Fe}^{2+}\right)\right.$ c. 0,5$]$ mas com teores relativamente baixos em álcalis $\left[(\mathrm{Na}+\mathrm{K})_{\mathrm{A}}<0,5\right]$, apontando para magnésio-riebeckita (Figuras 8A e 8B).
Como fases minerais acessórias em proporção não superior a $1 \%$, ocorrem zircão e, mais raramente, titanita, na forma de cristais subédricos a euédricos. Apatita ocorre como grãos prismáticos tipicamente aciculares, frequentemente como inclusões nas fases minerais principais.

\section{Subenxame Princesa Isabel}

Ao microscópio a textura é hipidiomórfica a xenomórfica, inequigranular seriada, caracterizada pelo arranjo de cristais de feldspato alcalino subédricos. A fase máfica dominante é anfibólio azul, com apatita e titanita aparecendo como acessórios.

Os cristais de microclina são equidimensionais, subédricos, mostrando macla albita-periclina; eventualmente podem apresentar planos de macla em uma única direção. Feições texturais como micropertitas e extinção ondulante são pouco comuns.

O anfibólio é geralmente subédrico a anédrico, tendo sido observados alguns grãos euédricos com até $6 \mathrm{~mm}$. É comum apresentar-se em formas aciculares, dispostas em arranjos radiais (Figura 6C). Grande parte dos cristais 
Tabela 2D. Composições químicas de micas do subenxame Serra Talhada. Legenda: $\mathbf{c}=$ centro, $\mathbf{b}=$ borda.

\begin{tabular}{|c|c|c|c|c|c|c|c|c|}
\hline \multirow{3}{*}{ Dique } & \multicolumn{8}{|c|}{ DKST-01 } \\
\hline & 1 & 2 & 3 & 4 & 5 & 6 & 7 & 8 \\
\hline & c & c & b & c & b & c & b & b \\
\hline $\mathrm{SiO}_{2}$ & 36,05 & 35,82 & 36,02 & 36,22 & 35,77 & 35,58 & 36,98 & 35,03 \\
\hline $\mathrm{TiO}_{2}$ & 5,90 & 7,46 & 7,89 & 7,60 & 7,58 & 6,81 & 6,04 & 8,79 \\
\hline $\mathrm{Al}_{2} \mathrm{O}_{3}$ & 15,19 & 15,86 & 15,76 & 15,87 & 16,88 & 16,27 & 16,16 & 14,44 \\
\hline $\mathrm{FeO}$ & 14,81 & 11,92 & 13,49 & 14,13 & 11,21 & 13,85 & 11,26 & 16,41 \\
\hline $\mathrm{MnO}$ & 0,23 & 0,05 & 0,07 & 0,12 & 0,07 & 0,13 & 0,06 & 0,14 \\
\hline $\mathrm{MgO}$ & 14,26 & 15,57 & 14,69 & 14,14 & 15,40 & 14,80 & 16,77 & 11,77 \\
\hline $\mathrm{CaO}$ & 0,04 & 0,00 & 0,04 & 0,00 & 0,01 & 0,00 & 0,03 & 0,00 \\
\hline $\mathrm{BaO}$ & 0,00 & 0,91 & 0,75 & 0,06 & 0,76 & 1,19 & 0,00 & 2,55 \\
\hline $\mathrm{Na}_{2} \mathrm{O}$ & 0,38 & 0,40 & 0,54 & 0,43 & 0,21 & 0,44 & 0,15 & 0,10 \\
\hline $\mathrm{K}_{2} \mathrm{O}$ & 9,70 & 9,50 & 9,00 & 9,57 & 9,69 & 9,26 & 10,22 & 8,88 \\
\hline $\mathrm{F}$ & 0,32 & 0,28 & 0,21 & 0,50 & 0,55 & 0,42 & 0,61 & 0,51 \\
\hline $\mathrm{Cl}$ & 0,03 & 0,06 & 0,06 & 0,03 & 0,04 & 0,10 & 0,08 & 0,05 \\
\hline \multirow[t]{2}{*}{$\mathrm{Cr}_{2} \mathrm{O}_{3}$} & 0,13 & 0,00 & 0,03 & 0,00 & 0,03 & 0,01 & na & 0,00 \\
\hline & 96,91 & 97,82 & 98,52 & 98,65 & 98,16 & 98,84 & 98,37 & 98,67 \\
\hline $\mathrm{O}-\mathrm{F}, \mathrm{Cl}$ & 0,14 & 0,13 & 0,10 & 0,22 & 0,24 & 0,20 & 0,27 & 0,22 \\
\hline Total & 96,77 & 97,69 & 98,42 & 98,43 & 97,92 & 98,64 & 98,10 & 98,45 \\
\hline $\mathrm{Si}$ & 5,343 & 5,221 & 5,226 & 5,261 & 5,181 & 5,193 & 5,325 & 5,244 \\
\hline Al IV & 2,652 & 2,722 & 2,692 & 2,714 & 2,819 & 2,769 & 2,675 & 2,545 \\
\hline $\mathrm{Fe}^{3+}$ & 0,005 & 0,057 & 0,082 & 0,025 & 0,000 & 0,011 & 0,000 & 0,211 \\
\hline SOMA TETRAÉDRICA & 8,000 & 8,000 & 8,000 & 8,000 & 8,000 & 8,000 & 8,000 & 8,000 \\
\hline Al IV & 0,000 & 0,000 & 0,000 & 0,000 & 0,061 & 0,000 & 0,066 & 0,000 \\
\hline $\mathrm{Ti}$ & 0,658 & 0,818 & 0,861 & 0,830 & 0,825 & 0,748 & 0,654 & 0,989 \\
\hline $\mathrm{Fe}^{2+}$ & 1,831 & 1,396 & 1,554 & 1,691 & 1,357 & 1,680 & 1,356 & 1,843 \\
\hline $\mathrm{Cr}$ & 0,015 & 0,000 & 0,004 & 0,000 & 0,003 & 0,001 & 0,000 & 0,000 \\
\hline $\mathrm{Mn}$ & 0,028 & 0,006 & 0,008 & 0,015 & 0,009 & 0,016 & 0,008 & 0,018 \\
\hline $\mathrm{Mg}$ & 3,152 & 3,384 & 3,176 & 3,061 & 3,326 & 3,220 & 3,599 & 2,627 \\
\hline SOMA OCTAÉDRICA & 5,684 & 5,604 & 5,603 & 5,597 & 5,581 & 5,665 & 5,683 & 5,477 \\
\hline $\mathrm{Ba}$ & 0,000 & 0,052 & 0,042 & 0,003 & 0,043 & 0,068 & 0,000 & 0,150 \\
\hline $\mathrm{Ca}$ & 0,007 & 0,000 & 0,007 & 0,000 & 0,001 & 0,000 & 0,005 & 0,000 \\
\hline $\mathrm{Na}$ & 0,108 & 0,113 & 0,152 & 0,120 & 0,060 & 0,123 & 0,042 & 0,029 \\
\hline $\mathrm{K}$ & 1,834 & 1,766 & 1,665 & 1,774 & 1,790 & 1,724 & 1,877 & 1,695 \\
\hline SOMA INTERCAMADA & 1,949 & 1,931 & 1,866 & 1,897 & 1,894 & 1,915 & 1,924 & 1,874 \\
\hline Total cátions & 15,633 & 15,535 & 15,469 & 15,494 & 15,475 & 15,580 & 15,607 & 15,351 \\
\hline $\mathrm{F}$ & 0,299 & 0,257 & 0,195 & 0,459 & 0,500 & 0,387 & 0,554 & 0,483 \\
\hline $\mathrm{Cl}$ & 0,016 & 0,032 & 0,031 & 0,015 & 0,018 & 0,049 & 0,039 & 0,023 \\
\hline
\end{tabular}

maiores têm zonação pleocroica, de tons azulados no centro passando a matizes levemente esverdeadas nas bordas. Apresentam relativa variação composicional entre tipos sódicos e sódicos-cálcicos (Figura 8A). A proporção de álcalis no sítio estrutural A dita a variação observada nos anfibólios sódicos, dominantemente entre magnésio-riebeckita $\left[(\mathrm{Na}+\mathrm{K})_{\mathrm{A}}<0,5\right]$ (Figura $8 \mathrm{~B}$ ) e ferro-ekermanita-arfvedsonita $\left[(\mathrm{Na}+\mathrm{K})_{\mathrm{A}} \geq 0,5\right]$. Composições de ferro-richterita com $\left[(\mathrm{Ca}+\mathrm{Na})_{\mathrm{B}} \geq 1\right]$ definem os tipos sódicos-cálcicos, de ocorrência subordinada.

\section{Subenxame Tavares}

Compreende rochas com textura tipicamente subvulcânica, definida por cristais de feldspato alcalino imersos em matriz fanerítica fina dominantemente constituída por ripas de feldspato e, menos comumente, anfibólio. Piroxênio e anfibólio também ocorrem como microfenocristais.

Os microfenocristais de feldspato são tabulares euédricos a subédricos, equidimensionais, com tamanhos variando entre 0,5 e $2 \mathrm{~mm}$. Geminação polissintética é larga- 

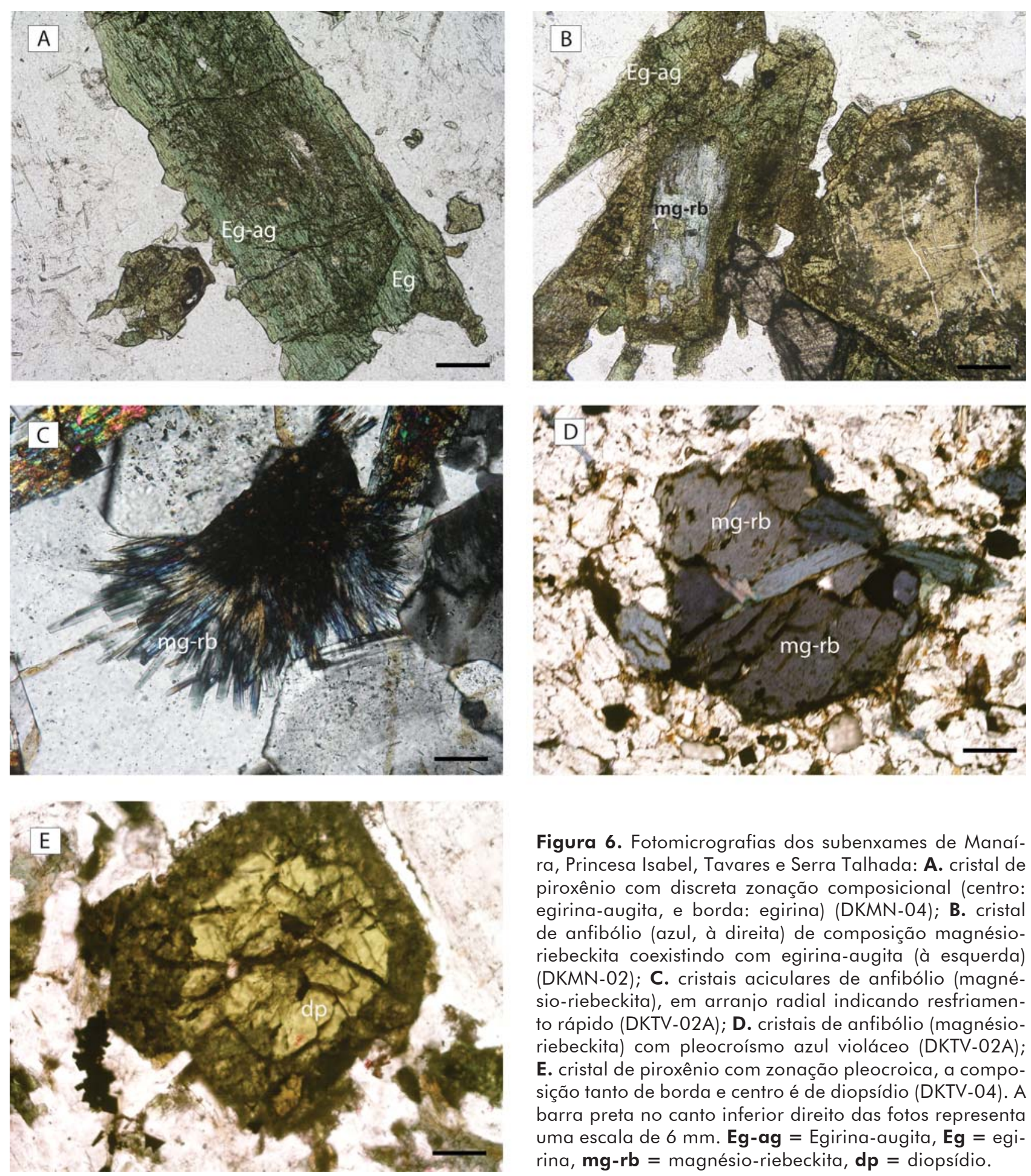

Figura 6. Fotomicrografias dos subenxames de Manaíra, Princesa Isabel, Tavares e Serra Talhada: A. cristal de piroxênio com discreta zonação composicional (centro: egirina-augita, e borda: egirina) (DKMN-04); B. cristal de anfibólio (azul, à direita) de composição magnésioriebeckita coexistindo com egirina-augita (à esquerda) (DKMN-02); C. cristais aciculares de anfibólio (magnésio-riebeckita), em arranjo radial indicando resfriamento rápido (DKTV-02A); D. cristais de anfibólio (magnésioriebeckita) com pleocroísmo azul violáceo (DKTV-02A); E. cristal de piroxênio com zonação pleocroica, a composição tanto de borda e centro é de diopsídio (DKTV-04). A barra preta no canto inferior direito das fotos representa uma escala de $6 \mathrm{~mm}$. Eg-ag = Egirina-augita, Eg = egirina, $\mathbf{m g - r b}=$ magnésio-riebeckita, $\mathbf{d p}=$ diopsídio. 
mente observada. Sua composição química evidencia uma solução sólida entre tipos sódicos e potássicos (centro: $\mathrm{Ab}_{48,7} \mathrm{An}_{1,2} \mathrm{Or}_{30,4}$ a Ab ${ }_{65,9} \mathrm{An}_{3,2} \mathrm{Or}_{47,8}$, e borda: $\mathrm{Ab}_{55,0} \mathrm{An}_{1,6} \mathrm{Or}_{35,8}$ a $\left.\mathrm{Ab}_{60,5} \mathrm{An}_{3,7} \mathrm{Or}_{42,8}\right)$. Estão igualmente presente na matriz, todavia apresentando-se como cristais ripiformes, subeuedrais, com grau incipiente de sericitização.

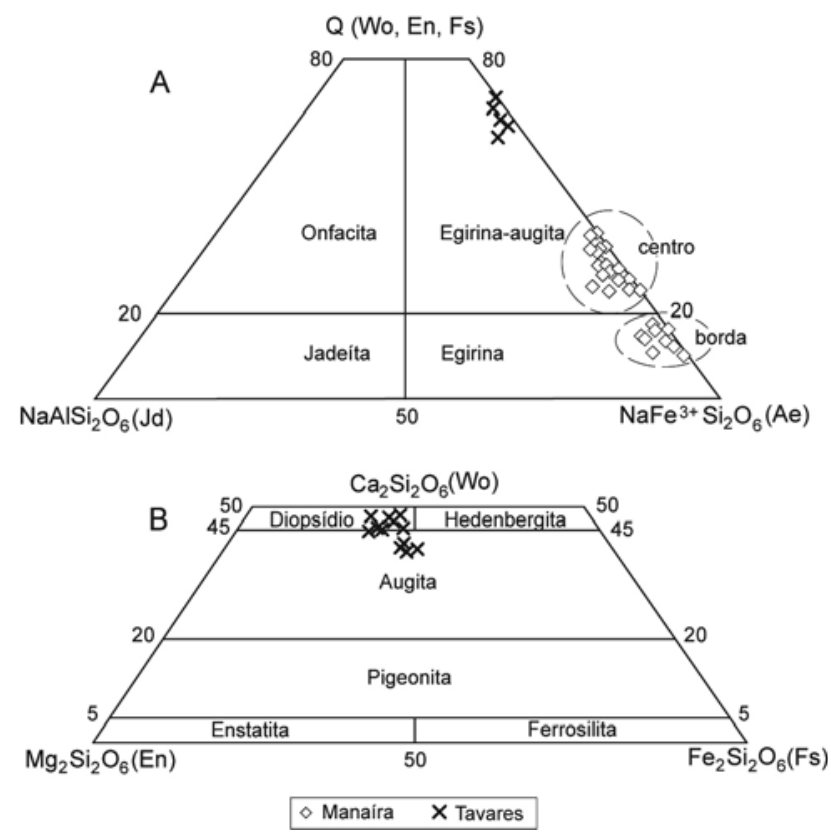

Figura 7. Diagrama de classificação para piroxênios (Morimoto et al., 1988): A. sódicos, dos subenxames Manaíra e Tavares; B. cálcicos, do subenxame Tavares.

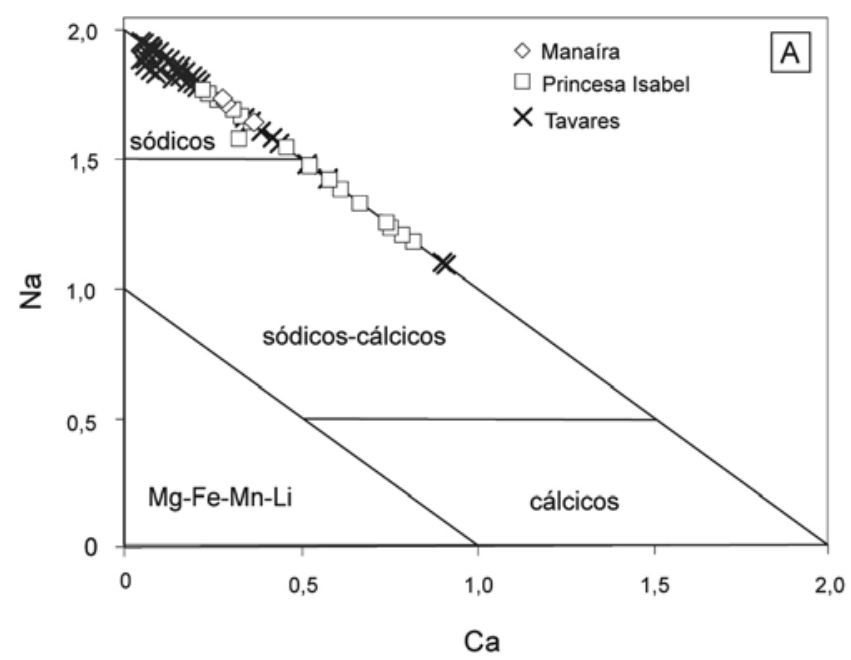

Anfibólio é a fase máfica mais expressiva, com hábito e composições variáveis (Figura 8A). O tipo dominante ocorre como cristais euédricos a subédricos, com dimensões entre 1 - 2,5 mm, e pleocroísmo variando entre azul violáceo e azul escuro (Figura 6D). Também ocorre como agregados aciculares, radiais, por vezes com alteração para óxido de ferro. Sua composição é de um anfibólio sódico, com $\left[(\mathrm{Na}+\mathrm{K})_{\mathrm{A}}<\right.$ $0,5],\left(\mathrm{Na}_{\mathrm{B}} \geq 1,5\right)$, e $\mathrm{Mg} \#\left[\mathrm{Mg} /\left(\mathrm{Mg}+\mathrm{Fe}^{2+}\right)\right]$ em torno de 0,5. A proporção variável de ${ }^{\mathrm{VI}} \mathrm{Al}$ em relação a $\mathrm{Fe}^{3+}$ classifica-o como magnésio-riebeckita e ferro-glaucofana (Figura 8B). Um tipo subordinado de anfibólio, com pleocroísmo em tons de verde aparece isolado ou formando mantos em torno do anfibólio azul. Sua composição é sódico-cálcica, tipo winchita. O piroxênio ocorre ora formando agregados, subédricos a euédricos, por vezes exibindo leve zonação definida por discretas variações pleocroicas, em tons de verde. Sua composição é essencialmente egirina-augita (Mg\# 0,64-0,71) (Figura 7A). Um segundo tipo ocorre como cristais isolados, com zonação pleocroica discreta a ausente (Figura 6E), sendo sua composição cálcica, variando entre diopsídio e augita $(\mathrm{Mg \#}$ entre 0,62 e 0,75 ) (Figura 7B).

\section{Subenxame Serra Talhada}

Ao microscópio a textura geral é fanerítica fina, representada principalmente por cristais xenomórficos de microclina, de granulação bastante homogênea. Sericita aparece pervasivamente como produto de alteração tardia, em especial ao longo dos planos de macla polissintética. Nos cristais maiores, a sericita tende a acompanhar o zonamento concêntrico.

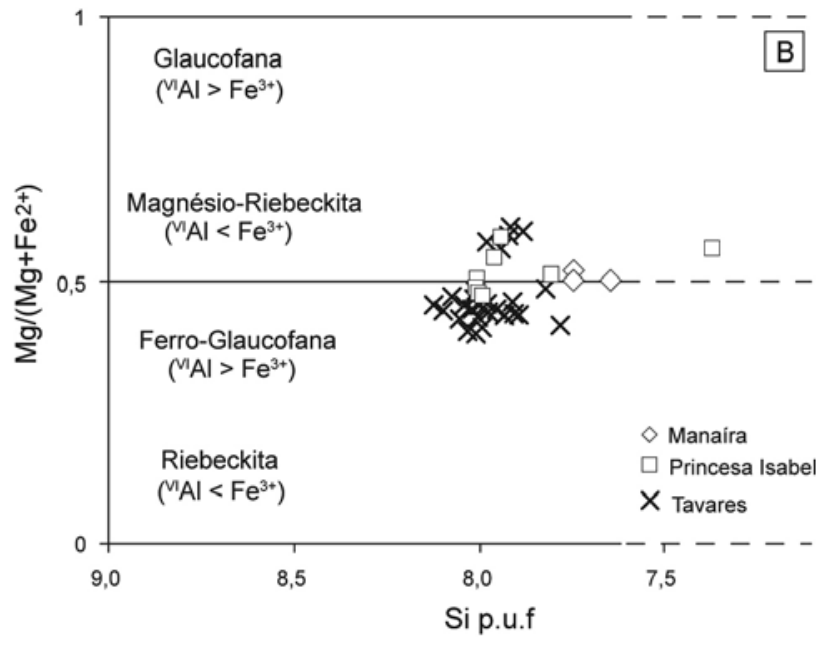

Figura 8. Diagramas de classificação para anfibólios (Leake, 1997): A. Na vs. Ca; B. Mg/(Mg+Fe $\left.{ }^{2+}\right)-S i$, onde os parâmetros químicos/estruturais são: $(\mathrm{Na}+\mathrm{K})_{\mathrm{A}}<0,5 ; \mathrm{Na}_{\mathrm{B}} \geq 1,5 ;\left(\mathrm{Mg}+\mathrm{Fe}^{2+}+\mathrm{Mn}^{2+}\right)>2,5$; $\left({ }^{\mathrm{V}} \mathrm{Al}\right.$ ou $\left.\mathrm{Fe}^{3+}\right)>\mathrm{Mn}^{3+} ; \mathrm{Li}^{2}<0,5$; $\left(\mathrm{Mg}\right.$ ou $\left.\mathrm{Fe}^{2+}\right)>\mathrm{Mn}^{2+}$. 
A fase máfica dominante é a biotita, com $\mathrm{Fe}^{2+} /\left(\mathrm{Fe}^{2+}+\right.$ $\mathrm{Mg}$ ) entre 0,25 - 0,4 e IV Al entre 1,2 - 1,4. O conteúdo em $\mathrm{BaO}$ é baixo (< que 1,2), associado a valores de $\mathrm{TiO}_{2}$ que variam entre 5,9 e 7,9, com apenas uma análise (ponto 8; Tabela 2.D) mostrando valores mais elevados para esses óxidos. Ocorre preferencialmente como cristais isolados, de até $0,8 \mathrm{~mm}$ em seu eixo maior, mas também formando pequenos agregados entre feldspatos. Em geral apresenta pleocroísmo em tons de castanho a castanho avermelhado; alteração para clorita é determinada por variações pleocroicas em tons esverdeados e pequenas inclusões de óxidos ao longo dos planos de clivagem.

\section{LITOQUÍMICA E GEOQUÍMICA ISOTÓPICA}

Um conjunto de dezoito amostras representativas de todos os quatro subenxames foi selecionado para análises litoquímicas e isotópicas. Foram determinados os teores para elementos maiores, menores/traços, e terras-raras. Os resultados são expressos em termos de $\%$ em peso para os óxidos, e em ppm para os demais, todos listados na Tabela 3. A concentração dos óxidos foi dosada por fluorescência de raios-X, no Laboratório de FRX do IGc/USP; detalhes sobre procedimento analítico estão descritos no Apêndice C. As análises de elementos maiores foram recalculadas para uma base livre de voláteis (segundo parâmetros de Irvine e Baragar, 1971), totalizando 100\%. Os valores recalculados são também apresentados na Tabela 3, sendo estes os dados analíticos plotados nos diagramas per- tinentes. As concentrações de elementos menores, traços e terras-raras foram dosadas por espectrometria de massa com plasma indutivamente acoplado (ICP-MS), no Acme Analytical Laboratories Ltda, Canadá.

As razões isotópicas ${ }^{87} \mathrm{Sr} /{ }^{86} \mathrm{Sr},{ }^{143} \mathrm{Nd} /{ }^{144} \mathrm{Nd}\left(=\varepsilon_{\mathrm{Nd}}\right)$ e ${ }^{206,207,208} \mathrm{~Pb} /{ }^{204} \mathrm{~Pb}$ foram determinadas para o mesmo conjunto analisado para litoquímica em rocha total. Os valores apresentados são aqueles iniciais, recalculados para idade de $600 \mathrm{Ma}$. As análises foram realizadas nos laboratórios específicos do Centro de Pesquisas Geocronológicas do IGc/USP. Todo o conjunto de dados está listado na Tabela 4. A rotina dos procedimentos analíticos está descrita no Apêndice D.

\section{Elementos maiores}

Em termos de conteúdo de sílica as amostras definem um espectro de saturação que varia em 59 - 69\%, combinado a teores de álcalis entre 9 - 16\%. Esses valores permitem classificar geoquimicamente os diques em sienitos (subenxames Tavares, Manaíra e Princesa Isabel) e álcali-granitos (subenxame Serra Talhada) (Figura 9A), todos saturados em sílica; exceção é a amostra DKTV-01 (subenxame Tavares) a qual tem características distintas, com álcalis total $>15 \%$ e ausência de quartzo-normativo. Com respeito à saturação em alumina, os diques dos subenxames Tavares, Manaíra e Princesa Isabel têm afinidade peralcalina (Figura 12), com tendência potássica a ultrapotássica $\left(\mathrm{K}_{2} \mathrm{O}\right.$ entre c. $7-13 \%$; $\% \mathrm{~K}_{2} \mathrm{O} / \mathrm{Na}_{2} \mathrm{O}>2$, segundo Foley et al., 1987). A afinidade
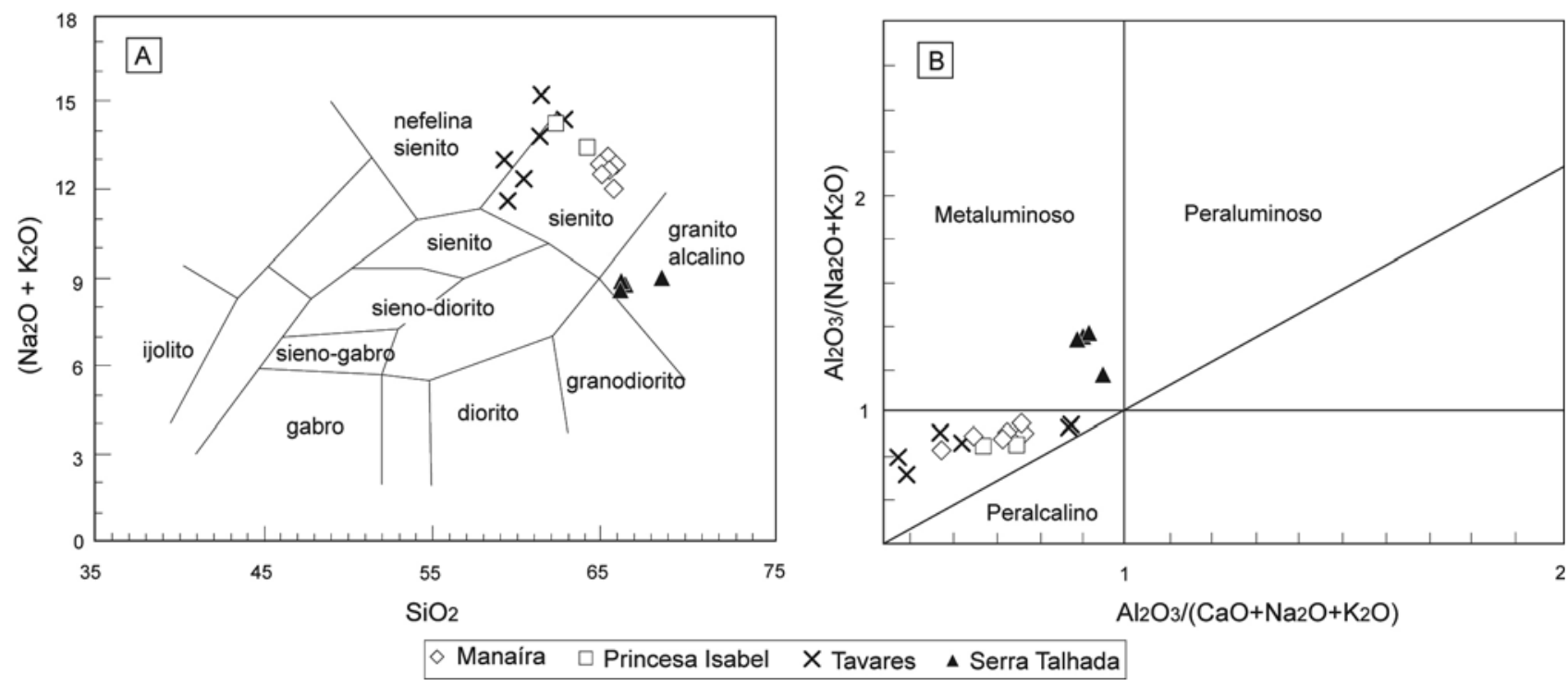

Figura 9. Diagramas de classificação geoquímica: A. álcalis total vs. sílica (Cox et al., 1979); B. índice de saturação em alumina (índice de Shand). 


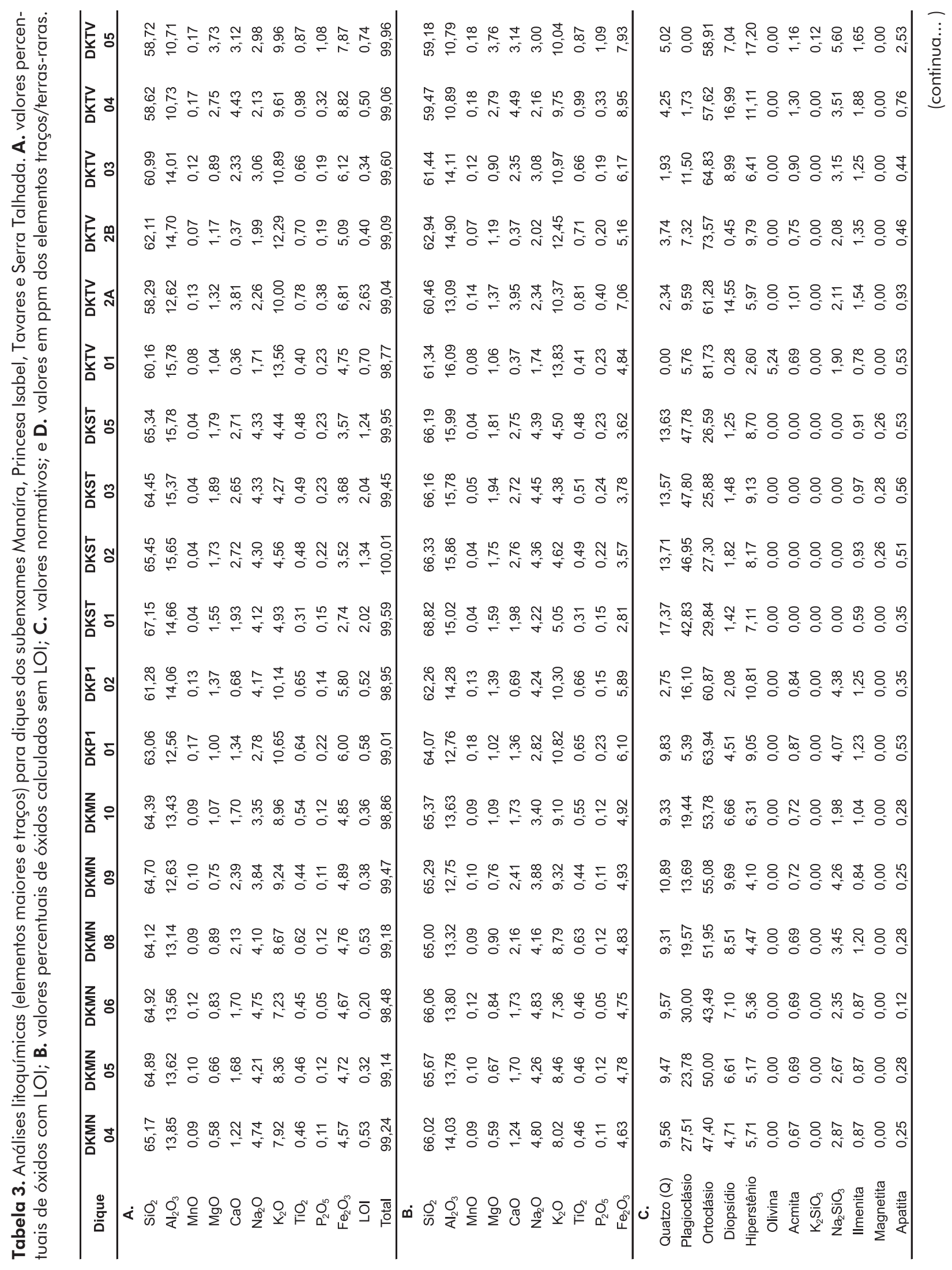




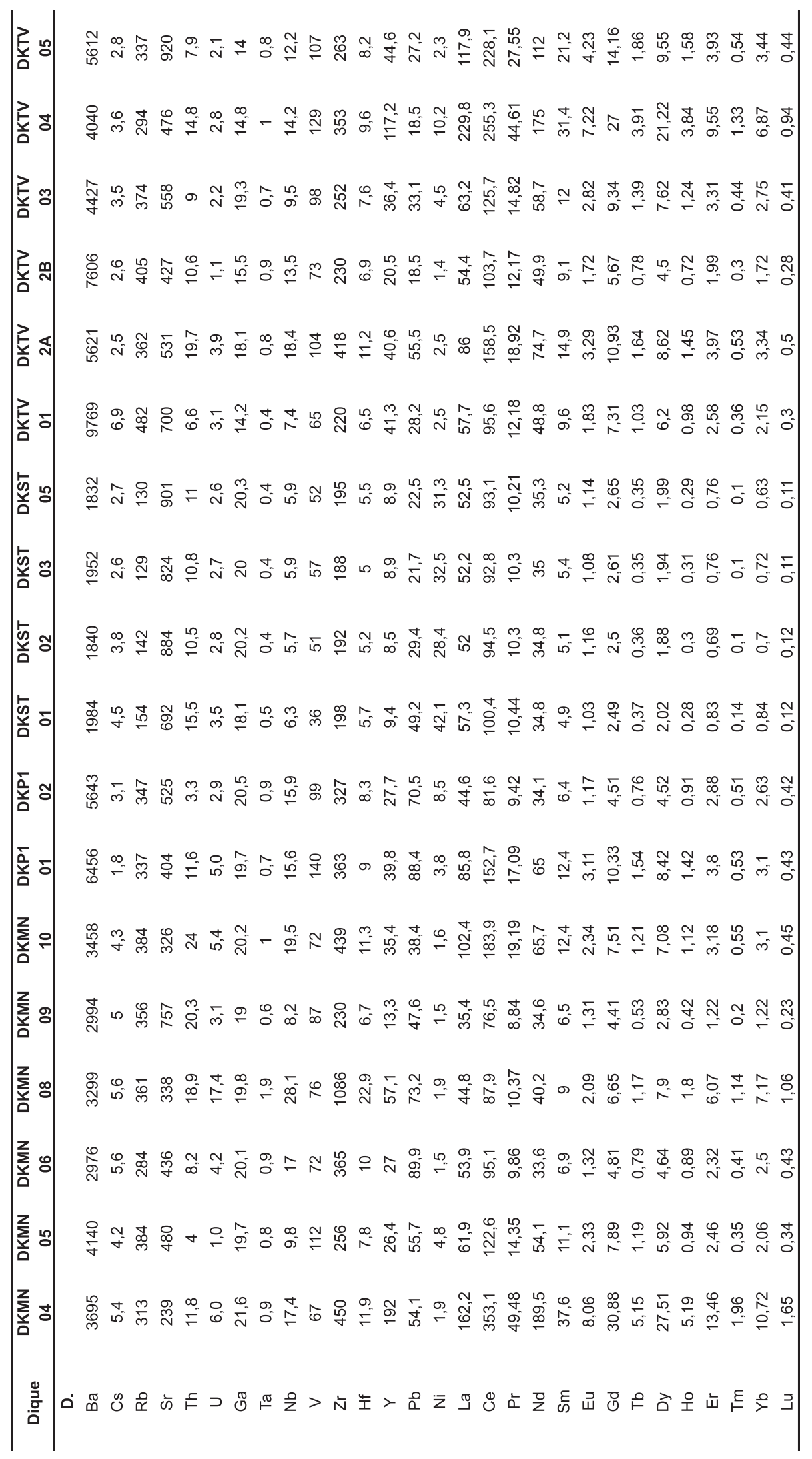


Tabela 4. Análises isotópicas $\mathrm{Sr}, \mathrm{Nd}$ e Pb para diques dos subenxames Manaíra, Princesa Isabel, Tavares e Serra Talhada. $\mathrm{Em} \mathbf{A}$, as razões isotópicas de $\mathrm{Sr}, \mathrm{Nd}$ e $\mathrm{Pb}$ com subscrito $(0)$ correspondem a valores atuais $(t=0)$, enquanto que em $\mathbf{B}$, são listadas as razões com subscrito (i), calculadas para $\dagger=600 \mathrm{Ma}$. Os valores de $\varepsilon_{\mathrm{Nd}}$ foram calculados a partir da equação: $10^{4}\left\{\left[\left({ }^{143} \mathrm{Nd} /{ }^{144} \mathrm{Nd}\right)_{\text {medido }} / 0,51264\right]-1\right\}$. $\mathrm{T}_{\mathrm{DM}}$ é uma idade-modelo calculada com relação ao manto empobrecido, cujas razões atuais são: ${ }^{147} \mathrm{Sm} /{ }^{144} \mathrm{Nd}=0,222 \mathrm{e}^{143} \mathrm{Nd} /{ }^{144} \mathrm{Nd}=0,513114$. As razões isotópicas ${ }^{206,207} \mathrm{~Pb} / 204 \mathrm{~Pb}$ foram corrigidas para fracionamento isotópico de $0,11 \%$ u.m.a., enquanto as razões ${ }^{208} \mathrm{~Pb} /{ }^{204} \mathrm{~Pb}$ foram corrigidas para o valor de 0,07\% u.m.a.

\begin{tabular}{|c|c|c|c|c|c|c|c|c|c|}
\hline Dique & DKMN-04 & DKMN-05 & DKMN-06 & DKMN-08 & DKMN-09 & DKMN-10 & DKP1-01 & DKP1-02 & DKST-01 \\
\hline \multicolumn{10}{|l|}{ A. } \\
\hline${ }^{87} \mathrm{Sr} /{ }^{86} \mathrm{Sr}(0)$ & 0,72794 & 0,72852 & 0,72467 & 0,73526 & 0,72225 & 0,73903 & 0,72931 & 0,72386 & 0,71495 \\
\hline erro $(1 \sigma)$ & 0,00007 & 0,00005 & 0,00011 & 0,00002 & 0,00007 & 0,00010 & 0,00005 & 0,00004 & 0,00004 \\
\hline $\mathrm{Rb} / \mathrm{Sr}$ (calc) & 1,31 & 0,80 & 0,65 & 1,07 & 0,47 & 1,18 & 0,83 & 0,66 & 0,22 \\
\hline${ }^{143} \mathrm{Nd} / /^{144} \mathrm{Nd}(0)$ & 0,511693 & 0,511581 & 0,511595 & 0,511655 & 0,511513 & 0,511465 & 0,511434 & 0,511591 & 0,511242 \\
\hline erro $(1 \sigma)$ & 0,000013 & 0,000014 & 0,000008 & 0,000011 & 0,000012 & 0,000017 & 0,000009 & 0,000010 & 0,000009 \\
\hline${ }^{147} \mathrm{Sm} /{ }^{144} \mathrm{Nd}$ & 0,1137 & 0,1191 & 0,111 & 0,1313 & 0,1129 & 0,1067 & 0,1264 & 0,1115 & 0,0815 \\
\hline erro $(1 \sigma)$ & 0,0007 & 0,0007 & 0,0007 & 0,0008 & 0,0007 & 0,0006 & 0,0008 & 0,0007 & 0,0005 \\
\hline $\operatorname{ENd}(0)$ & $-18,4$ & $-20,6$ & $-20,3$ & $-19,2$ & $-21,9$ & $-22,9$ & $-23,5$ & $-20,4$ & $-27,2$ \\
\hline${ }^{206} \mathrm{~Pb}{ }^{204} \mathrm{~Pb}$ & 17,312 & 16,869 & 17,153 & 17,806 & 17,125 & 17,808 & 17,047 & 16,932 & 16,726 \\
\hline erro $(1 \sigma)$ & 0,006 & 0,005 & 0,039 & 0,020 & 0,007 & 0,013 & 0,014 & 0,011 & 0,007 \\
\hline${ }^{207} \mathrm{~Pb} /{ }^{204} \mathrm{~Pb}$ & 15,476 & 15,406 & 15,443 & 15,548 & 15,494 & 15,543 & 15,45 & 15,397 & 15,47 \\
\hline erro $(1 \sigma)$ & 0,006 & 0,006 & 0,042 & 0,023 & 0,006 & 0,011 & 0,014 & 0,011 & 0,006 \\
\hline${ }^{208} \mathrm{~Pb} /{ }^{204} \mathrm{~Pb}$ & 37,696 & 37,269 & 37,609 & 37,951 & 37,926 & 38,459 & 37,493 & 37,201 & 37,439 \\
\hline erro $(1 \sigma)$ & 0,007 & 0,006 & 0,042 & 0,022 & 0,007 & 0,012 & 0,015 & 0,011 & 0,006 \\
\hline \multicolumn{10}{|l|}{ B. } \\
\hline${ }^{87} \mathrm{Sr} /{ }^{86} \mathrm{Sr}(\mathrm{i})$ & 0,69545 & 0,70867 & 0,70851 & 0,70875 & 0,71059 & 0,70978 & 0,70862 & 0,70747 & 0,70944 \\
\hline${ }^{143} \mathrm{Nd} /{ }^{144} \mathrm{Nd}(\mathrm{i})$ & 0,511246 & 0,511113 & 0,511159 & 0,511139 & 0,511069 & 0,511045 & 0,510937 & 0,511153 & 0,510922 \\
\hline $\mathrm{ENd}(\mathrm{i})$ & $-12,1$ & $-14,7$ & $-13,8$ & $-14,2$ & $-15,5$ & $-16,0$ & $-18,1$ & $-13,9$ & $-18,4$ \\
\hline TDM (Ga) & 1,99 & 2,26 & 2,08 & 2,44 & 2,23 & 2,17 & 2,66 & 2,09 & 2,02 \\
\hline${ }^{206} \mathrm{~Pb}{ }^{204} \mathrm{~Pb}$ (i) & 16,555 & 16,154 & 16,411 & 17,003 & 16,386 & 17,004 & 16,315 & 16,211 & 16,025 \\
\hline${ }^{207} \mathrm{~Pb}{ }^{204} \mathrm{~Pb}$ (i) & 15,431 & 15,363 & 15,399 & 15,500 & 15,450 & 15,495 & 15,406 & 15,354 & 15,428 \\
\hline${ }^{208} \mathrm{~Pb}{ }^{204} \mathrm{~Pb}$ (i) & 37,676 & 37,218 & 37,586 & 37,939 & 37,904 & 38,453 & 37,475 & 37,166 & 37,433 \\
\hline Dique & DKST-02 & DKST-03 & DKST-05 & DKTV-01 & DKTV-2A & DKTV-2B & DKTV-03 & DKTV-04 & DKTV-05 \\
\hline \multicolumn{10}{|l|}{ A. } \\
\hline${ }^{87} \mathrm{Sr} /{ }^{86} \mathrm{Sr}(0)$ & 0,71201 & 0,71201 & 0,71181 & 0,70799 & 0,72419 & 0,73072 & 0,72454 & 0,72277 & 0,71664 \\
\hline erro $(1 \sigma)$ & 0,00006 & 0,00007 & 0,00008 & 0,00003 & 0,00009 & 0,00006 & 0,00003 & 0,00010 & 0,00003 \\
\hline $\mathrm{Rb} / \mathrm{Sr}$ (calc) & 0,16 & 0,16 & 0,14 & 0,69 & 0,68 & 0,95 & 0,67 & 0,62 & 0,37 \\
\hline${ }^{143} \mathrm{Nd} /{ }^{144} \mathrm{Nd}(0)$ & 0,511301 & 0,511323 & 0,511294 & 0,511637 & 0,511613 & 0,511481 & 0,51156 & 0,511875 & 0,511716 \\
\hline erro $(1 \sigma)$ & 0,000010 & 0,000013 & 0,000011 & 0,000009 & 0,000009 & 0,000011 & 0,000008 & 0,000008 & 0,000013 \\
\hline${ }^{147} \mathrm{Sm} /{ }^{144} \mathrm{Nd}$ & 0,0851 & 0,0851 & 0,0845 & 0,1212 & 0,1442 & 0,1095 & 0,1205 & 0,1196 & 0,1057 \\
\hline erro $(1 \sigma)$ & 0,0005 & 0,0005 & 0,0005 & 0,0007 & 0,0009 & 0,0006 & 0,0007 & 0,0007 & 0,0007 \\
\hline $\mathrm{ENd}(0)$ & $-26,1$ & $-25,7$ & $-26,2$ & $-19,5$ & $-20,0$ & $-22,6$ & $-21,0$ & $-14,9$ & $-18,0$ \\
\hline${ }^{206} \mathrm{~Pb}{ }^{204} \mathrm{~Pb}$ & 16,755 & 16,739 & 16,73 & 17,065 & 16,913 & 16,705 & 17,122 & 17,068 & 17,032 \\
\hline erro $(1 \sigma)$ & 0,009 & 0,005 & 0,018 & 0,012 & & 0,005 & 0,008 & & \\
\hline${ }^{207} \mathrm{~Pb} /{ }^{204} \mathrm{~Pb}$ & 15,454 & 15,464 & 15,449 & 15,44 & 15,42 & 15,421 & 15,434 & 15,401 & 15,383 \\
\hline erro $(1 \sigma)$ & 0,009 & 0,005 & 0,019 & 0,011 & & 0,005 & 0,013 & & \\
\hline${ }^{208} \mathrm{~Pb}{ }^{204} \mathrm{~Pb}$ & 37,205 & 37,246 & 37,215 & 37,342 & 37,36 & 37,243 & 37,578 & 37,613 & 37,323 \\
\hline erro $(1 \sigma)$ & 0,008 & 0,006 & 0,016 & 0,011 & & 0,004 & 0,009 & & \\
\hline \multicolumn{10}{|l|}{ B. } \\
\hline${ }^{87} \mathrm{Sr} /{ }^{86} \mathrm{Sr}(\mathrm{i})$ & 0,70803 & 0,70813 & 0,70824 & 0,69094 & 0,70729 & 0,70718 & 0,70792 & 0,70742 & 0,70756 \\
\hline${ }^{143} \mathrm{Nd} /{ }^{144} \mathrm{Nd}(\mathrm{i})$ & 0,510966 & 0,510988 & 0,510962 & 0,511160 & 0,511046 & 0,511050 & 0,511086 & 0,511405 & 0,511300 \\
\hline ENd(i) & $-17,5$ & $-17,1$ & $-17,6$ & $-13,8$ & $-16,0$ & $-15,9$ & $-15,2$ & $-9,0$ & $-11,0$ \\
\hline TDM (Ga) & 2,01 & 1,99 & 2,01 & 2,22 & 2,92 & 2,2 & 2,32 & 1,84 & 1,83 \\
\hline${ }^{206} \mathrm{~Pb}{ }^{204} \mathrm{~Pb}$ (i) & 16,051 & 16,036 & 16,028 & 16,332 & 16,194 & 16,006 & 16,383 & 16,334 & 16,302 \\
\hline${ }^{207} \mathrm{~Pb}{ }^{204} \mathrm{~Pb}$ (i) & 15,412 & 15,422 & 15,407 & 15,396 & 15,377 & 15,379 & 15,390 & 15,357 & 15,339 \\
\hline${ }^{208} \mathrm{~Pb}{ }^{204} \mathrm{~Pb}$ (i) & 37,196 & 37,238 & 37,207 & 37,310 & 37,352 & 37,228 & 37,557 & 37,600 & 37,293 \\
\hline
\end{tabular}


peralcalina é igualmente comprovada pelos valores do índice agpaítico (Liégeois e Black, 1987), os quais variam entre 1,11 e 1,47. Por sua vez, os diques do subenxame Serra Talhada apresentam razões $\mathrm{Al}_{2} \mathrm{O}_{3} /\left(\mathrm{CaO}+\mathrm{Na}_{2} \mathrm{O}+\mathrm{K}_{2} \mathrm{O}\right)$ mais altas e valores para o índice agpaítico entre $0,76-0,83$, indicando afinidade metaluminosa.
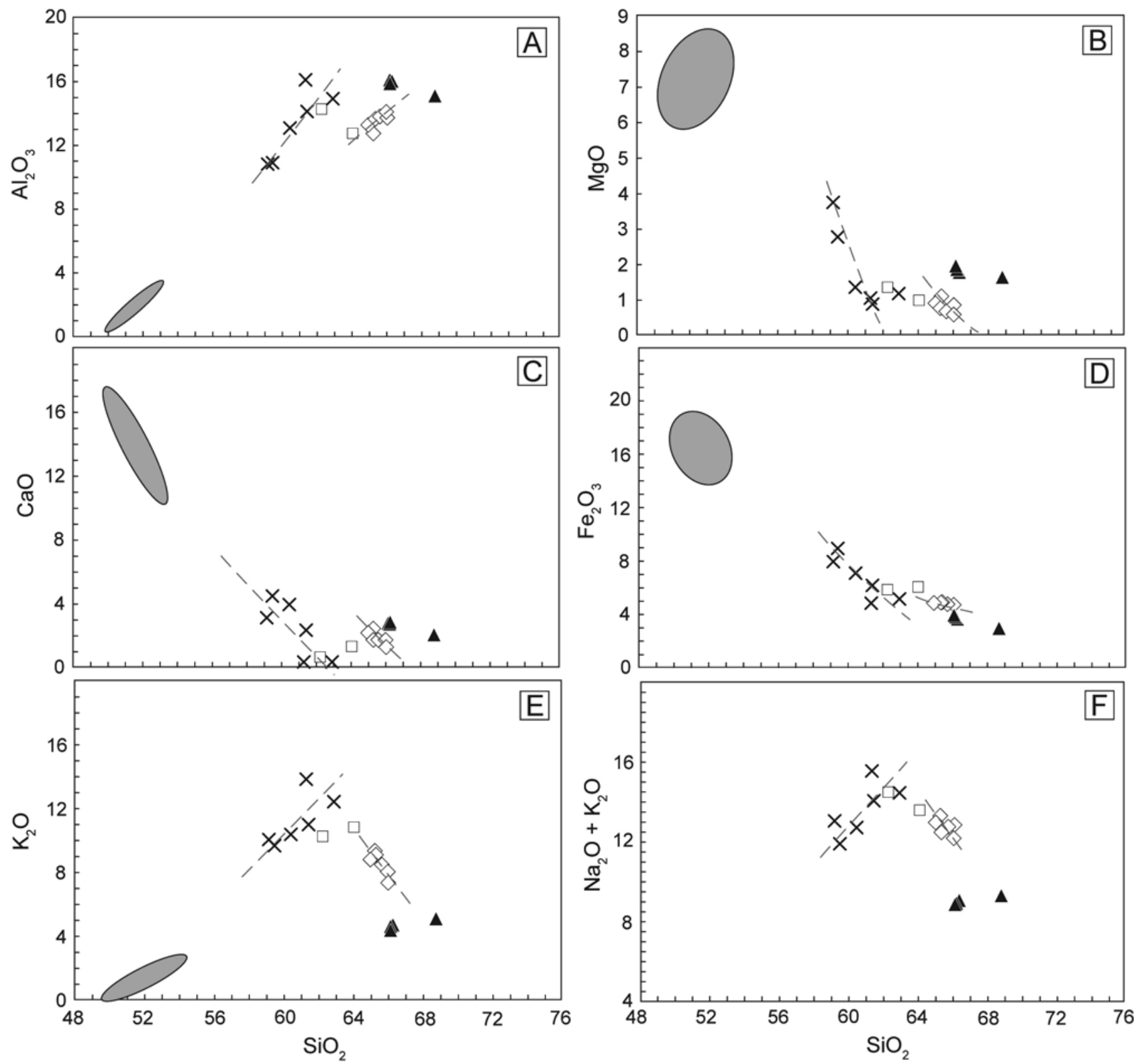

Manaíra $\square$ Princesa Isabel $\times$ Tavares ^ Serra Talhada

Figura 10. Diagramas de variação entre óxidos (tipo Harker) para as amostras dos subenxames Manaíra, Princesa Isabel, Tavares e Serra Talhada. Para comparação, são ilustradas as composições de piroxenitos (campo cinza) associados ao sienito de Triunfo (dados de Ferreira et al., 1994). 
e Tavares mostram comportamentos semelhantes quanto a $\mathrm{Al}_{2} \mathrm{O}_{3}, \mathrm{MgO}, \mathrm{CaO}$ e $\mathrm{Fe}_{2} \mathrm{O}_{3}$ (Figuras 10A a 10D). O teor de alumina nos dois grupos aumenta proporcionalmente com a diferenciação, enquanto que álcalis $(\mathrm{Na}+\mathrm{K})$ apresenta comportamentos contrastantes quando os dois grupos são considerados individualmente. Se tomados em conjunto, é possível visualizar um trend com forte inflexão entre os dois grupos de amostras, sugerindo que feldspato e as fases máficas sódicas (principalmente anfibólio) fracionaram mais significativamente a partir de teores de sílica em torno de 63\% (Figuras 10E e 10F). Anfibólio sódico em Manaíra é claramente tardio, produto de desestabilização de piroxênio que, por sua vez, apresenta zonamento cálcico-sódico, com teores maiores de $\mathrm{Na}$ (egirina) nas bordas.

$\mathrm{MgO}, \mathrm{Fe}_{2} \mathrm{O}_{3}$ e $\mathrm{CaO}$ apresentam comportamento decrescente com relação à diferenciação, sugerindo que fracionamento de piroxênio (egirina-augita em Manaíra e Tavares, e também os tipos cálcicos neste último subenxame) foi constante ao longo de toda a história de cristalização do enxame de diques. Ainda, o comportamento de Ti e P (não ilustrado) nos dois subenxames indica o controle pelo fracionamento de titanita e apatita, respectivamente.

O número reduzido de análises (apenas duas) do subenxame Princesa Isabel não permite comentar sobre a importância de cristalização fracionada como mecanismo petrogenético. Da mesma forma, a avaliação do subenxame Serra Talhada fica prejudicada face a relativa homogeneidade composicional entre as amostras, uma vez que três delas apresentam valores para óxidos estritamente semelhantes.

\section{Elementos traços e terras-raras}

As Figuras 11 e 12 ilustram o comportamento dos elementos traços em diagramas multielementos e terras-raras, respectivamente. Analisados em conjunto, o padrão de variação de elementos incompatíveis é semelhante em todos os quatro subenxames, com pequenas diferenças que podem refletir a história de fracionamento mineral individual de cada dique. A saber:
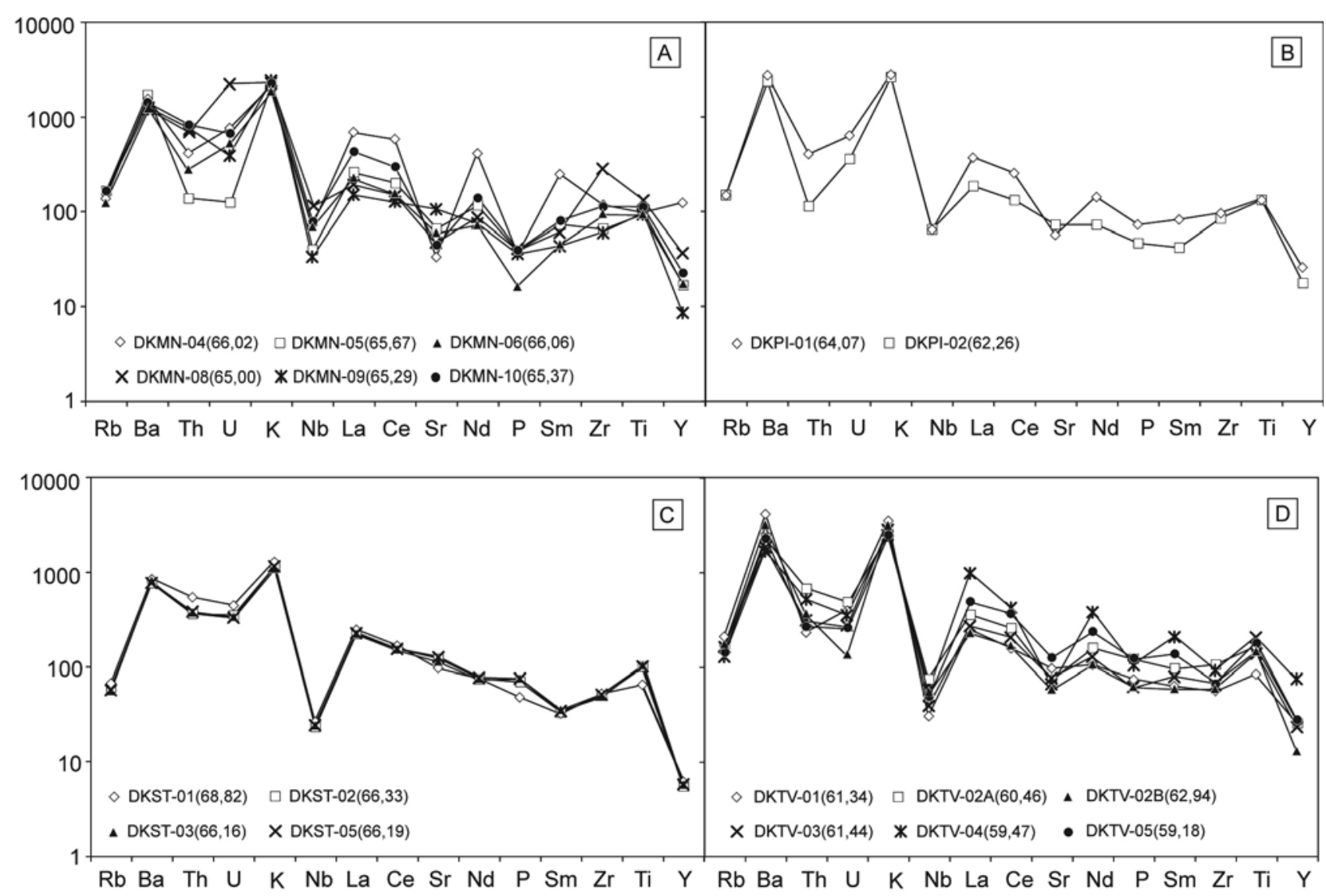

Figura 11. Espectros multielementos (spidergrams) para as amostras dos subenxames. A. Manaíra. B. Princesa Isabel. C. Serra Talhada. D. Tavares. Os teores de sílica (\%) são indicados para cada amostra, em parênteses. Os fatores de normalização adotados são aqueles do condrito de Sun e McDonough (1989). 
1. enriquecimento pronunciado nos elementos fortemente incompatíveis ( $\mathrm{Rb}, \mathrm{Ba}, \mathrm{Th}, \mathrm{U}$ e $\mathrm{K})$, mas com teores significativamente mais elevados em $\mathrm{Ba}$ e $\mathrm{K}$ em comparação a Rb, Th e U, induzindo à falsas anomalias negativas nestes últimos elementos. As variações discretas de $\mathrm{Rb}, \mathrm{Ba}$ e $\mathrm{K}$ não são correlacionadas diretamente com aumento de sílica. Para Rb e K as amostras mais evoluídas dos subenxames Manaíra e Tavares têm, de fato, valores mais elevados nestes elementos, muito embora a correlação não seja linear. As concentrações das amostras do subenxame Serra Talhada são invariantes, enquanto as duas amostras de Princesa Isabel não revelam qualquer tendência bem definida;

2. o grau de enriquecimento em relação ao condrito (Sun e McDonough, 1989) diminui progressivamente para direita do diagrama, com flutuações observadas especialmente nos valores normalizados de Th, U, Nb, Sr, P (e Zr);

3. é notória, nos espectros individuais de todas as amostras, a presença de forte anomalia negativa de $\mathrm{Nb}$, sem qualquer correlação com o grau de diferenciação (ver teores de $\mathrm{SiO}_{2}$ para cada amostra, na legenda da Figura 11);
4. anomalias negativas em $\mathrm{Sr}$ (e mais restritamente, em P) são observadas nas amostras dos subenxames Manaíra (exceção de DKMN-09) e Tavares, e em apenas uma das amostras do subenxame Princesa Isabel (DKPI-01).

Com respeito aos elementos terras-raras, as razões $(\mathrm{La} /$ $\mathrm{Yb})_{\mathrm{N}}$ são amplamente variáveis. Parte das amostras do subenxame Manaíra, aquelas de Tavares e uma das amostras de Princesa Isabel (DKPI-01) têm razões $(\mathrm{La} / \mathrm{Yb})_{\mathrm{N}}$ similares, com valores médios entre 17 - 23. Três amostras do subenxame Manaíra (DKMN-04, -06, -08) e a amostra DKPI02 apresentam valores mais baixos [( $\mathrm{La} / \mathrm{Yb})_{\mathrm{N}}$ entre 4 e 11]. As amostras do subenxame Serra Talhada são significantemente mais fracionadas, apresentando os valores mais elevados para $(\mathrm{La} / \mathrm{Yb})_{\mathrm{N}}$, entre aproximadamente 46 - 56.

Além do padrão comum de fracionamento, os espectros ETR dos diques mostram grau moderado de empobrecimento em $\mathrm{Eu}$, indicado pelos valores calculados da razão $\mathrm{Eu} / \mathrm{Eu}^{*}$. Esses valores concentram-se preferencialmente em torno de 0,67 - 0,84 para os diques dos subenxames Manaíra, Princesa

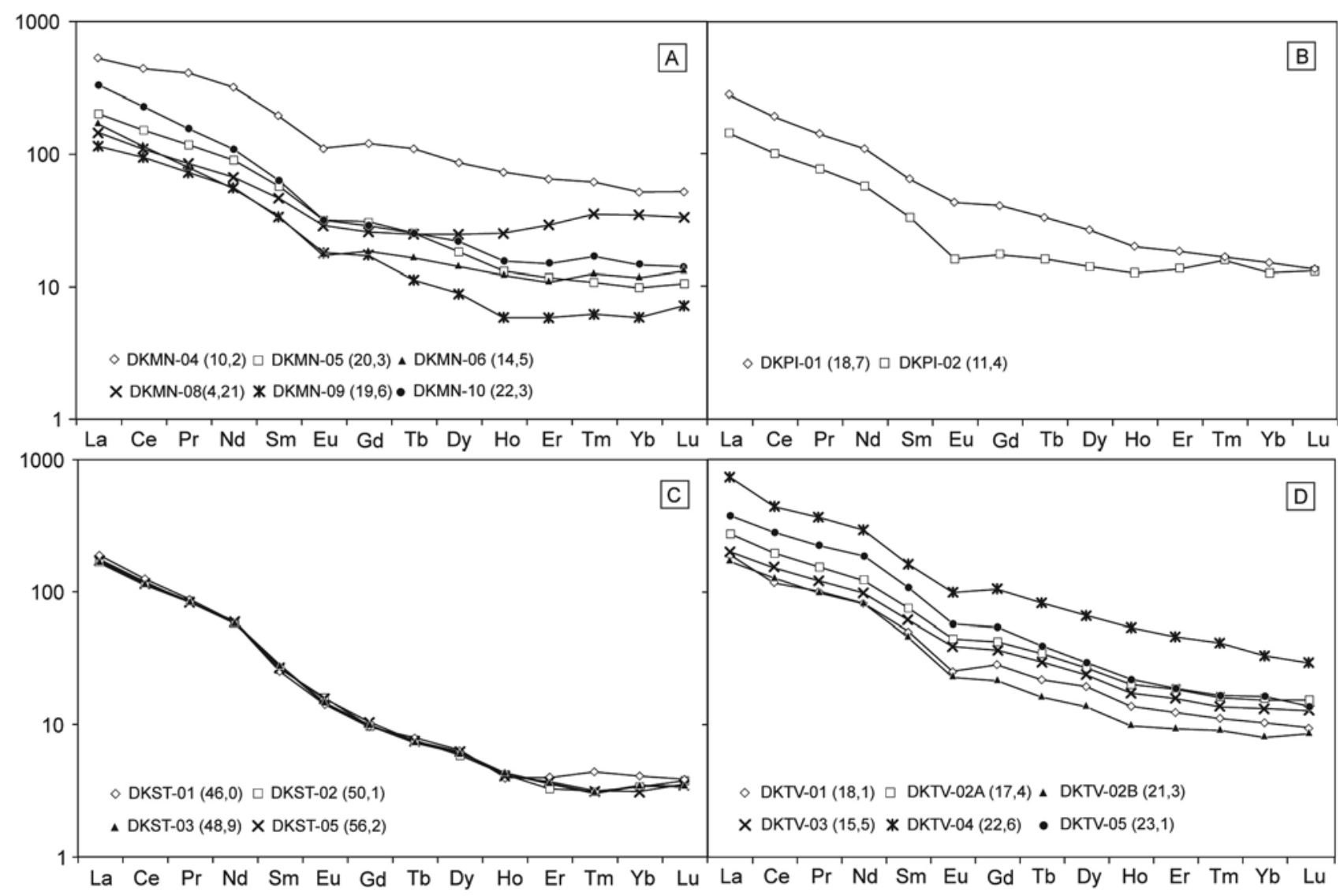

Figura 12. Espectros das concentrações de elementos terras-raras para os subenxames. A. Manaíra. B. Princesa Isabel. C. Serra Talhada. D. Tavares. Os valores das razões $(\mathrm{La} / \mathrm{Yb})_{N}$ são indicados em parênteses. Os fatores de normalização adotados são aqueles do condrito de Boynton (1984). 
Isabel e Tavares, e valores mais próximos a 1 para os diques do subenxame Serra Talhada $(0,88$ - 0,99). A variação no grau da anomalia de Eu é em parte correlacionada ao grau de diferenciação: quatro das amostras de Manaíra definem uma tendência a valores mais elevados de $\mathrm{Eu} / \mathrm{Eu}^{*}$ com aumento de sílica, enquanto comportamento inverso é observado para o conjunto de amostras do subenxame Tavares.

\section{Geoquímica Isotópica}

\section{Composição isotópica de $\mathrm{Sr}$}

Como um conjunto, as razões isotópicas ${ }^{87} \mathrm{Sr} /{ }^{86} \mathrm{Sr}$ iniciais dos diques dos quatro subenxames são heterogêneas, entre 0,70718 - 0,70875, incluindo ainda composições menos e mais radiogênicas que 0,700 e 0,709, respectivamente. Essas variações são superiores aos erros inerentes à análise propriamente dita, menores que 0,0001. Quando avaliados isoladamente, os subenxames guardam alguma semelhança. Por exemplo, nota-se que as razões ${ }^{87} \mathrm{Sr} /{ }^{86} \mathrm{Sr}$ (bem como $\mathrm{Rb} / \mathrm{Sr}$ ) das amostras dos subenxames Manaíra e Tavares são mais heterogêneas comparativamente àquelas dos subenxames Princesa Isabel e Serra Talhada. Em geral, essas razões não apresentam correlação positiva entre si (Figura 13A); em Tavares a correlação é sugerida se excluídas as amostras DKTV-01 (não incluída no gráfico) e -03, respectivamente a menos e mais radiogênica do conjunto. Nesse caso, as razões ${ }^{87} \mathrm{Sr} /{ }^{86} \mathrm{Sr}$ tornam-se progressivamente menos radiogênicas com decréscimo da razão $\mathrm{Rb} / \mathrm{Sr}$ e o teor de $\mathrm{SiO}_{2}$, em um padrão que parece ser incompatível com contaminação crustal. Para as amostra do subenxame Manaíra o com- portamento é inverso, com aumento muito discreto da razão ${ }^{87} \mathrm{Sr} /{ }^{86} \mathrm{Sr}$ associado a aumento significativo das razões $\mathrm{Rb} / \mathrm{Sr}$ e também teores de sílica. Todavia, para considerar essa tendência, três amostras do conjunto devem ser descartadas.

Uma amostra de cada um dos subenxames Manaíra (DKMN-04) e Tavares (DKTV-01) têm assinaturas isotópica ${ }^{87} \mathrm{Sr} /{ }^{86} \mathrm{Sr}$ inferiores a 0,700 . Apesar da semelhança, essas composições menos radiogênicas parecem estar relacionadas a fatores distintos em cada caso. Para a amostra DKMN-04, a razão ${ }^{87} \mathrm{Sr} /{ }^{86} \mathrm{Sr}$ atual é estreitamente similar às demais do grupo e mesmo dos subenxames Princesa Isabel e Tavares; todavia, a concentração mais baixa de $\mathrm{Sr}$ influencia fortemente no valor mais alto da razão $\mathrm{Rb} / \mathrm{Sr}$, calculada em 1,3 (ver Tabela 4). Já para a amostra DKTV01 a razão $\mathrm{Rb} / \mathrm{Sr}$ se compara àquelas das demais amostras do conjunto, sendo o valor mais baixo da razão ${ }^{87} \mathrm{Sr} /{ }^{86} \mathrm{Sr}$ provavelmente reflexo de heterogeneidades na fonte.

\section{Composição isotópica de $\mathrm{Nd}$}

À semelhança das composições isotópicas de Sr, as razões ${ }^{143} \mathrm{Nd} /{ }^{144} \mathrm{Nd}$ (ou $\varepsilon_{\mathrm{Nd}(600)}$ ) iniciais são igualmente heterogêneas. Os subenxames Manaíra, Tavares e as duas amostras de Princesa Isabel apresentam valores de $\varepsilon_{\mathrm{Nd}(600)}$ entre $-13,8$ e -16, enquanto que as amostras do subenxame Serra Talhada são discretamente mais radiogênicas, com pequenas variações em torno de $-17,5$. Apesar da significativa variação composicional, não é observada uma tendência de correlação entre as razões isotópicas de $\mathrm{Sr}$ e $\mathrm{Nd}$ (Figura 13B). Os dados do subenxame Manaíra, no entanto, parecem definir três grupos, representados respectivamente: 1. pela amostra

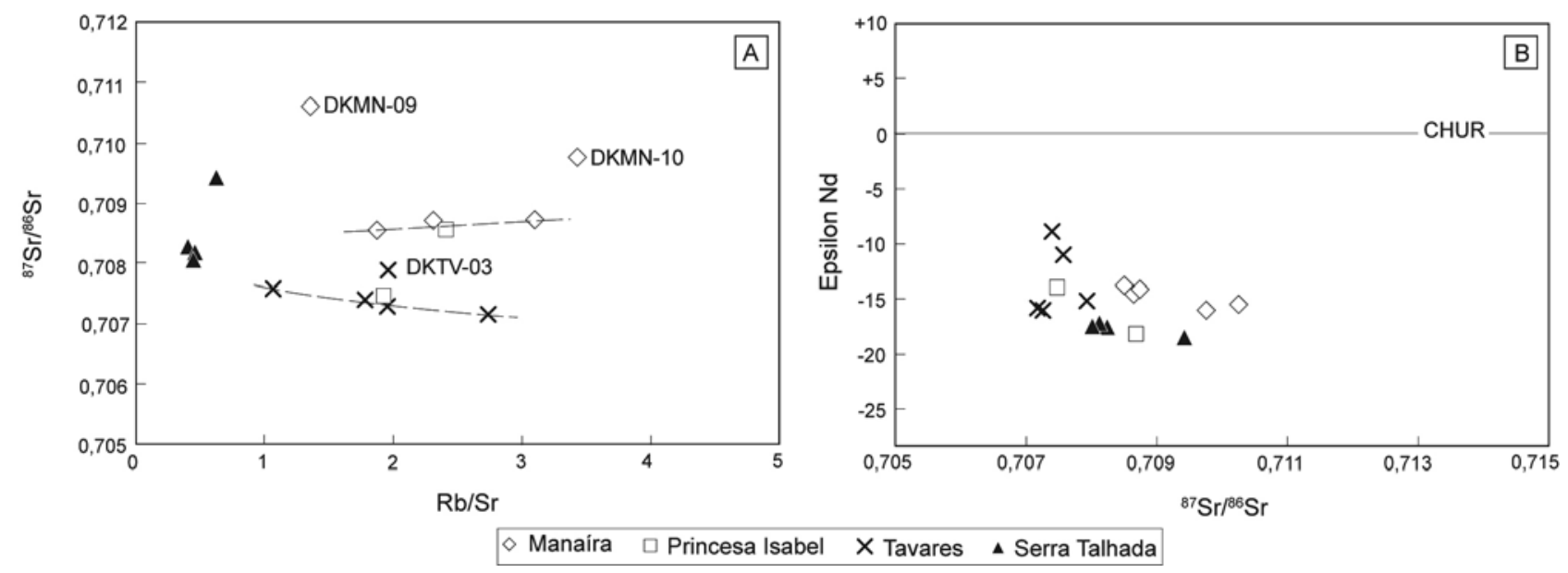

Figura 13. Diagramas de correlação entre: A. razões $\mathrm{Rb} / \mathrm{Sr}$ e ${ }^{87} \mathrm{Sr} /{ }^{86} \mathrm{Sr}$; B. razões ${ }^{87} \mathrm{Sr} /{ }^{86} \mathrm{Sr}$ e $\varepsilon_{\mathrm{Nd}}$. Os valores das razões isotópicas de $\mathrm{Sr}$ e $\mathrm{Nd}$ foram recalculados para a idade de $600 \mathrm{Ma}$, sendo que as amostras DKMNN-04 e DKTV-01 não estão incluídas tendo em vista suas razões menos radiogênicas em $\mathrm{Sr}(<0,700)$. As linhas segmentadas em $\mathbf{A}$ representam possíveis tendências de correlação entre os dados dos subenxames de Manaíra e Tavares. 
DKMN-04, menos radiogênica (0,695 e -12) (não ilustrada na referida figura), 2. pelas amostras DKMN-05, -06 e -08, com valores $\varepsilon_{\mathrm{Nd}} \mathrm{e}^{87} \mathrm{Sr} /{ }^{86} \mathrm{Sr}$ intermediários (c. 0,7085 e -14), e finalmente 3. pelas amostras DKMN-09 e -10, com valores mais radiogênicos $(>0,7097 \mathrm{e}<-15)$.

As amostras com $\varepsilon_{\mathrm{Nd}(600)}$ mais negativos dos subenxames Princesa Isabel (DKPI-01) e Serra Talhada (DKST01) são as mesmas que apresentam as razões ${ }^{87} \mathrm{Sr} /{ }^{86} \mathrm{Sr}$ mais elevadas de cada grupo. Coincidentemente, correspondem às amostras mais evoluídas (maior \% $\% \mathrm{SiO} 2$ e Q) e com maiores concentrações em elementos incompatíveis $(\mathrm{Rb}$, Ba, Th, U, ETR leves). Sendo assim, a possibilidade de contaminação com material (a encaixante regional?) mais radiogênico não deve ser totalmente excluída.

Com respeito às razões ${ }^{147} \mathrm{Sm} /{ }^{144} \mathrm{Nd}$, a maioria das amostras concentra-se entre 0,10 e 0,12 , à exceção daquelas do subenxame Serra Talhada cujos valores são bastante homogêneos em torno de 0,085 . A combinação das razões ${ }^{143} \mathrm{Nd} /{ }^{144} \mathrm{Nd}$ e ${ }^{147} \mathrm{Sm} /{ }^{144} \mathrm{Nd}$ forneceram valores de idadesmodelo Sm-Nd $\left(\mathrm{T}_{\mathrm{DM}}\right)$ paleoproterozoicas, entre 1,8 e 2,2 Ga. Idades $\mathrm{T}_{\mathrm{DM}}$ maiores que 2,4 foram calculadas para três amostras do conjunto (DKMN-08, DKPI-01, DKTV-02A) como resultado do fracionamento mais significativo entre $\mathrm{Sm}$ e $\mathrm{Nd}$, demonstrado pelos valores mais elevados das razões ${ }^{147} \mathrm{Sm} /{ }^{144} \mathrm{Nd}$ nessas amostras.

\section{Composição isotópica de $\mathrm{Pb}$}

Os valores das razões ${ }^{206} \mathrm{~Pb} / 204 \mathrm{~Pb},{ }^{207} \mathrm{~Pb} /{ }^{204} \mathrm{~Pb} \mathrm{e}^{208} \mathrm{~Pb} /{ }^{204} \mathrm{~Pb}$ iniciais de todo o conjunto de amostras refletem composições menos radiogênicas quando comparadas à média dos valores crustais, segundo Stacey e Kramers (1975) (Figura 14A). Significativa homogeneidade é observada especificamente entre as razões ${ }^{206} \mathrm{~Pb} /{ }^{204} \mathrm{~Pb}$, as quais se concentram em um intervalo estreito de valores, entre 16,01 e 16,56. Apenas duas amostras, ambas do subenxame Manaíra, apresentam valores discretamente mais elevados, em torno de 17 . As razões torogênicas ${ }^{208} \mathrm{~Pb} /{ }^{204} \mathrm{~Pb}$ são igualmente homogêneas. Contrariamente, as razões ${ }^{207} \mathrm{~Pb} /{ }^{204} \mathrm{~Pb}$ iniciais distribuem-se em uma faixa mais ampla de valores, entre 15,34 e 15,5, sugerindo contaminação (em proporções variáveis) com material antigo.

A Figura 14 ilustra também a representação gráfica dos dados isotópicos $\mathrm{Pb} / \mathrm{Pb}$ no modelo plumbotectônica de Doe e Zartmann (1979). A distribuição das amostras em ambos os gráficos correlacionando as razões ${ }^{207} \mathrm{~Pb} /{ }^{204} \mathrm{~Pb}$ e ${ }^{208} \mathrm{~Pb} /{ }^{204} \mathrm{~Pb}$ com ${ }^{206} \mathrm{~Pb} /{ }^{204} \mathrm{~Pb}$ mostram clara similaridade com os valores definidos para um reservatório misto - o orógeno, cuja assinatura isotópica reflete a contribuição (em proporções não exatamente definidas) de manto e crostas, superior e inferior, na gênese desses magmas.

\section{NATUREZA DA FONTE E IMPLICAÇÕES GEODINÂMICAS}

Reconhecer magmas gerados a partir de fusão de manto metassomatizado implica em observar nestes características geoquímicas e isotópicas indicativas de enriquecimento anômalo. Esse padrão geoquímico é largamente reconhecido na composição dos diques da região de Manaíra-Princesa Isabel. O padrão geral dos espectros multielementos de todas as amostras, dos quatro subenxames, são

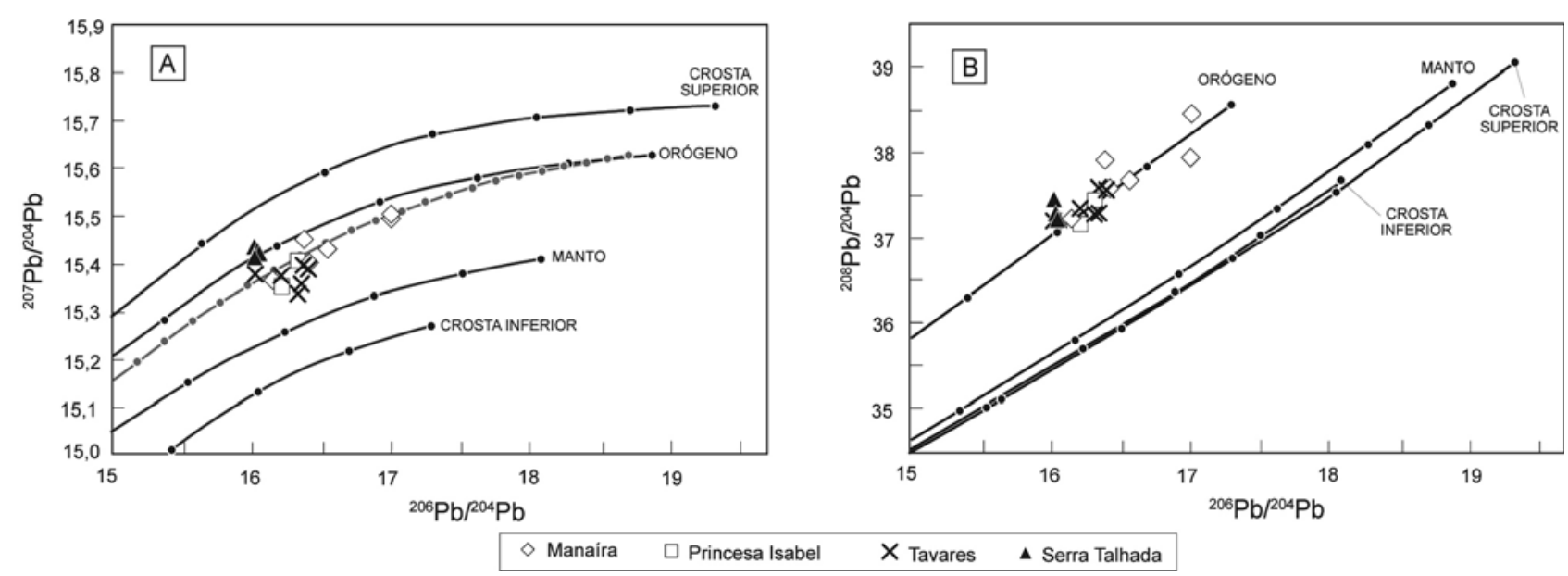

Figura 14. Diagramas de correlação entre: A. razões ${ }^{206} \mathrm{~Pb} /{ }^{204} \mathrm{~Pb}$ e ${ }^{207} \mathrm{~Pb} /{ }^{204} \mathrm{~Pb} ; \mathbf{B}$. razões ${ }^{206} \mathrm{~Pb} /{ }^{204} \mathrm{~Pb}$ e ${ }^{208} \mathrm{~Pb} /{ }^{204} \mathrm{~Pb}$, assumindo o modelo Plumbotectônica. Em A, a curva cinza representa a evolução global de Pb segundo Stacey e Kramers (1975), subdividida em intervalos de $100 \mathrm{Ma}$ (de 0 a 2,0 Ga). Os intervalos demarcados nas curvas orógeno, manto e crostas são de $400 \mathrm{Ma}$. 
semelhantes entre si, mostrando teores na ordem de 100 a 1000 vezes as proporções condríticas, sugerindo uma fonte enriquecida e comum. Além do enriquecimento em $\mathrm{Rb}$, $\mathrm{Ba}, \mathrm{Th}, \mathrm{U}$ e K, e ETR leves, a anomalia negativa em Nb é uma feição marcante.

Padrões fortemente fracionados em ETR leves com relação aos pesados são compatíveis com fusão (em pequenas proporções) de uma fonte tipo granada-peridotito, onde a presença de granada como fase residual na fonte implicaria na retenção de ETR pesados, explicando o empobrecimento relativo nestes elementos. A participação do manto como fonte é também indicada por dados $\delta^{18} \mathrm{O}$ c. $+8 \%$ a $+10 \%$ (Sial e Ferreira, 1990; Ferreira et al., 1998) obtidos em amostras desse magmatismo.

O envolvimento de um manto tipo granada-peridotito anomalamente enriquecido vem sendo sugerido como fonte comum para o magmatismo máfico shoshonítico (Jardim de Sá, 1994; Ferreira et al., 1998; Hollanda et al., 2003) e alcalino-peralcalino ultrapotássico (Sial e Ferreira, 1988; Ferreira et al., 1994, 1998; Guimarães et al., 2005) Neoproterozoico na Província Borborema oriental. As características geoquímicas dos diques aqui estudados permitem também incluí-los como representante do magmatismo peralcalino ultrapotássico dessa província, estendendo assim a hipótese de origem a partir de um manto antigo anomalamente enriquecido por um componente de subducção, assim explicando as anomalias negativas de $\mathrm{Nb}$. No presente caso, a hipótese é endossada pelo enriquecimento em elementos incompatíveis, aliado às altas razões ${ }^{87} \mathrm{Sr} /{ }^{86} \mathrm{Sr}$ iniciais $(>0,707)$ e valores fortemente negativos de $\varepsilon_{\mathrm{Nd}(600)}$ (em geral $<-12$ ), cujas variações não estão relacionadas a parâmetros que indiquem contaminação crustal pervasiva durante ascensão/alojamento. Além do que, o rápido transporte e resfriamento inerente a esses diques (relativamente pouco espessos com bordas de resfriamento bem desenvolvidas) são incompatíveis com tempo de residência crustal, em estado magmático, que poderia condicionar modificações químicas significativas; todavia, algum de contaminação crustal deve ter ocorrido tendo em vista a presença de zircões herdados do embasamento regional mais antigo.

A idade do evento de enriquecimento pode ser estimada com base no fracionamento relativo de $\mathrm{Sm}$ em relação a $\mathrm{Nd}$, ou seja, as razões $\mathrm{Sm} / \mathrm{Nd}$ na fonte tendem a decrescer durante o processo. Por exemplo, altas razões ${ }^{143} \mathrm{Nd} /{ }^{144} \mathrm{Nd}$ $\left(=\varepsilon_{\mathrm{Nd}}\right.$ positivos) aliadas a razões $\mathrm{Sm} / \mathrm{Nd}$ condríticas indicariam que o intervalo de tempo decorrido entre enriquecimento e fusão parcial da fonte foi relativamente curto; ao contrário, razões $\mathrm{Sm} / \mathrm{Nd}$ baixas $(<0,10$, por exemplo) associadas à razões ${ }^{143} \mathrm{Nd} /{ }^{144} \mathrm{Nd}$ baixas indicariam um evento metassomático antigo (segundo Cohen et al., 1984; Roden e Murthy, 1985). De fato, os valores de $\varepsilon_{\mathrm{Nd}(600)}$ muito negati- vos combinados a razões ${ }^{147} \mathrm{Sm} /{ }^{144} \mathrm{Nd}$ baixas determinados nas amostras estudadas forneceram idades TDM paleoproterozoicas, entre 1,8 - 2,2 Ga. Isso é fortemente sugestivo de que o evento metassomático capaz de imprimir uma assinatura enriquecida ao manto litosférico regional pode estar relacionado a processos de acreção crustal (em um cenário de margem convergente) Paleoproterozoicos, como já discutido amplamente na literatura. Esse manto enriquecido teria permanecido preservado até o Neoproterozoico quando então teria sido parcialmente fundido para gerar os magmas parentais dos inúmeros corpos granitoides e sieníticos que intrudem a Província Borborema.

Os dados de campo e várias evidências microtexturais indicam que o alojamento dos diques ocorreu em crosta relativamente rasa. Bordas resfriadas foram observadas nos diques intrusivos em metassedimentos de baixo grau a oeste da cidade de Manaíra e no subenxame Tavares. Nesse último, são comuns texturas subvulcânicas caracterizadas por fenocristais euédricos a subeuédricos de K-feldspato imersos em matriz homogênea, muito fina. No subenxame Manaíra são comuns a presença de apófises e corpos satélites ao dique principal cortando em alto ângulo a foliação metamórfica regional. É importante salientar que os diques não estão deformados pela tectônica regional e nem estão afetados pelo metamorfismo de baixo grau.

$\mathrm{O}$ enxame de diques estudado corta todas as estruturas do embasamento regional entre a Zona de Cisalhamento Juru-Belém e o sienito de Triunfo, o qual é representado por rochas eoneoproterozoicas do domínio Alto Pajeú, Complexo Riacho Gravatá e os granitoides brasilianos de Tavares e Princesa Isabel (cf. Figura 2). Assim, o magmatismo alcalino fissural foi uma feição tardia neste setor da Zona Transversal. Não existem dados geocronológicos disponíveis para o granito de Princesa Isabel, porém idades U/Pb em zircão no batólito de Tavares mostraram idades de cristalização em torno de $630 \mathrm{Ma}$ (Brito Neves et al., 2003). Essa idade seria, portanto, a idade máxima para o alojamento do enxame de diques de Manaíra-Princesa Isabel. A idade U/Pb (SHRIMP) de c. 600 Ma é consistente com as observações de campo, mostrando que o enxame resfriou rapidamente na crosta rasa, entre 600 - $605 \mathrm{Ma}$. Esses resultados indicam que o bloco crustal compreendido entre a Zona de Cisalhamento Juru-Belém e o sienito de Triunfo possui idades de resfriamento bastante precoces quando comparadas a outros setores da Zona Transversal, em geral entre 540 e 490 Ma (Monié et al., 1997; Corsini et al., 1998).

Em grande parte da porção setentrional da Província Borborema, a norte do Lineamento Patos, o principal período de atividade tectono-magmática ocorreu a 585 - 575 Ma (Souza et al., 2006). Ou seja, parte substancial da província estaria sendo invadida por granitos e deforman- 
do em alta temperatura na crosta intermediária. Um número restrito de plútons graníticos com idades similares também são encontrados na Zona Transversal - Itaporanga (585 Ma; Brito Neves et al., 2003), Campina Grande, Serra Redonda e Serra Branca (580 - 575 Ma; Guimarães et al., 2004; Archanjo et al., 2008). Considerando a idade de 600 Ma é possível interpretar que parte da Zona Transversal estaria sendo exumada nesse período, estando preservada do forte evento tectono-magmático que afetou o domínio Seridó-Jaguaribe, a norte, em torno de $580 \mathrm{Ma}$.

\section{CONCLUSÕES}

1. Os diques dos subenxames Manaíra, Princesa Isabel e Tavares constituem dominantemente sienitos saturados em sílica, com afinidade peralcalina, potássica a ultrapotássica $\left(\mathrm{K}_{2} \mathrm{O}\right.$ entre c. 7 - 13\%; $\left.\mathrm{K}_{2} \mathrm{O} / \mathrm{Na}_{2} \mathrm{O}>2\right)$. Por sua vez, o subenxame Serra Talhada é representado por álcali-granitos, com afinidade (fracamente)metaluminosa.

2. A assembleia mineral é dominada por microclina e anfibólio \pm clinopiroxênio sódicos, sendo principalmente reconhecidos Mg-riebeckita (e Fe-glaucofana) e egirina-augita. As variações composicionais nos anfibólios são especialmente ditadas pelas trocas catiônicas $\mathrm{Al} \Leftrightarrow \mathrm{Fe}$, bem como pelas proporções de álcalis $(\mathrm{Na}+\mathrm{K})$ no sítio $\mathrm{A}$ da estrutura desse mineral. A coexistência em equilíbrio de diopsídio-augita e egirina-augita no subenxame Tavares é indicada por feições texturais e químicas $(\mathrm{Mg \#} \mathrm{0,6-0,7).} \mathrm{A} \mathrm{presença} \mathrm{em} \mathrm{equilíbrio}$ de piroxênios sódicos e cálcicos é descrita por Ferreira e colaboradores (1994) como uma feição comum no sienito de Triunfo, cuja petrogênese parece estar relacionada a processos de imiscibilidade de líquidos sieníticos e piroxeníticos. $\mathrm{O}$ reconhecimento de feições petrográficas e químicas nos diques estudados à semelhança daquelas no plúton de Triunfo confirma a filiação comum desses produtos magmáticos.

3. O forte enriquecimento em elementos incompatíveis aliado à razões ${ }^{87} \mathrm{Sr} /{ }^{86} \mathrm{Sr}$ iniciais muito radiogênicas e $\varepsilon_{\mathrm{Nd}(\mathrm{t}=600)}$ fortemente negativos sugerem uma fonte comum. A anomalia negativa em $\mathrm{Nb}$ presente em todos os subenxames indica um componente de subducção envolvido na gênese desse magmatismo, provavelmente atuando como agente indutor do enriquecimento e fusão de um manto litosférico.

4. Idades modelo Sm-Nd entre 1,8 e 2,2 Ga (somados à razões ${ }^{207} \mathrm{~Pb} /{ }^{206} \mathrm{~Pb}$ variáveis) indicam que o enriquecimento pode ter sido antigo, provavelmente relacionado à geração de crosta (em ambiente de arco) paleoproterozoica.

5. Os valores das razões ${ }^{206,207,208} \mathrm{~Pb} /{ }^{204} \mathrm{~Pb}$ sugerem, $a$ priori, a participação de um componente não radiogênico interagindo com o manto litosférico enriquecido.

6. No contexto geodinâmico da Zona Transversal, a idade U-Pb SHRIMP em zircão de c. 600 Ma obtida para o magmatismo peralcalino fissural na região de ManaíraPrincesa Isabel define um cenário de relativa quiescência tectônica contrastando com intensa atividade tectonomagmática em c. $580 \mathrm{Ma}$.

\section{AGRADECIMENTOS}

À Fundação de Amparo à Pesquisa do Estado de São Paulo - FAPESP, pelo apoio financeiro ao projeto 04/08614-9 “O Cambro-Ordoviciano na Província Borborema”. Ao Dr. Ian McReath pelas sugestões ao manuscrito, bem como ao revisores, Dr. Affonso Brod e um anônimo, pelos valiosos comentários ao texto original.

\section{REFERÊNCIAS}

ALMEIDA, F. F. M.; HASUI, Y.; BRITO NEVES, B. B.; FUCK, R. A. Brazilian structural provinces: An introduction. Earth-Science Reviews, v. 17, p. 1-29, 1981.

ARCHANJO, C. J.; FETTER, A. Emplacement setting of the granite sheeted pluton of Esperança (Brasiliano orogen, northeastern Brazil). Precambrian Research, v. 135, p. 193-215, 2004.

ARCHANJO, C. J.; HOLLANDA, M. H. B. M.; RODRIGUES, S. W. O.; BRITO NEVES, B. B.; AMSTRONG, R. Fabrics of pre- and syntectonic granite plutons and chronology of shear zones in the Eastern Borborema Province, NE Brazil. Journal of Structural Geology, v. 30, p. 310-326, 2008.

BABINSKY, M.; VAN SCHUMS.; W. R., CHEMALE JR., F. Pb-Pb dating and $\mathrm{Pb}$ isotope geochemistry of Neoproterozoic carbonate rocks from the São Francisco Basin, Brazil: implications for the mobility of $\mathrm{Pb}$ isotopes during tectonism and metamorphism. Chemical Geology, v. 160, p. 177-199, 1999.

BAILEY, D. K. Mantle metasomatism: continuing chemical change within the Earth. Nature, v. 296, p. 525-530, 1972.

BITTAR, S. M. B. Faixa Piancó-Alto Brígida: terrenos tectono-estratigráficos sob regimes metamórficos e deformacionais contrastantes. 1998. 126 f. Tese (Doutorado) Instituto de Geociências, Universidade de São Paulo, São Paulo, 1998.

BONIN, B. A-type granites and related rocks: evolution of a concept, problems and prospects. Lithos, v. 97, p. 1-29, 2007. 
BOYNTON, W. R. Geochemistry of the rare earth elements: meteorite studies. In: HENDERSON, P. Rare Earth Element Geochemistry. Amsterdan, p. 63-114, 1984.

BRITO NEVES, B. B.; SANTOS, E. J.; VAN SCHMUS, W. R. Tectonic history of the Borborema Province, northeastern Brazil. In: CORDANI, U. G.; MILANI, E. J.; THOMAZ FILHO, A.; CAMPOS, D. A. Tectonic Evolution of South America. Rio de Janeiro: SBG, 2000. p. 151-182.

BRITO NEVES, B. B.; CAMPOS NETO, M. C.; VAN SCHMUS, W. R.; FERNANDES, T. M. G.; SOUZA, S. L. O Terreno Alto Moxotó no leste da Paraíba ("Maciço Caldas Brandão"). Revista Brasileira de Geociências, v. 31, p. 185-194, 2001.

BRITO NEVES, B. B.; PASSARELLI, C. R.; BASEI, M. A. S.; SANTOS, E. J. Idades U-Pb em zircão de alguns granitos clássicos da província Borborema. Geologia USP: Série Científica, v. 3, p. 25-38, 2003.

BRITO NEVES, B. B.; VAN SCHMUS, W. R.; KOZUCH, M.; SANTOS, E. J.; PETRONILHO, L. A zona tectônica Teixeira-Terra Nova: ZTTN, fundamentos da geologia regional e isotópica. Geologia USP: Série Científica, v. 5, p. $57-80,2005$.

COHEN, R. S.; ONIONS, R. K.; DAWSON, J. B. Isotope geochemistry of xenoliths from East Africa: implication for development of mantle reservoirs ant their interaction. Earth and Planetary Science Letters, v. 68, p. 209-220. 1984.

COMPSTON, W.; WILLIAMS, I. S.; KIRSHVINK, J. L.; ZANG, Z.; GUOGAN, M. A. Zircon U-Pb ages for the Early Cambrian time scale. Journal of Geological Society of London. v. 149, p. 171-184, 1992.

CORSINI, M.; LAMBERT-FIGUEIREDO, L.; CABY, R.; FERAUD, G.; RUFFETT, G.; VAUCHEZ, A. Thermal history of the Pan-African/Brasiliano Borborema Province of northeast Brazil deduced from ${ }^{39} \mathrm{Ar}^{/ 40} \mathrm{Ar}$ analysis. Tectonophysics, v. 285, p. 103-117, 1998.

COX, K. G.; BELL, J. D.; PANKHURST, R. J. The interpretation of igneous rocks. George, Allen \& Unwin: London, 1979. 449 p.

DANTAS,E.L.;VANSCHMUS,W.R.;HACKSPACHER, P. C.; BRITO NEVES, B. B.; FETTER, A.; CORDANI, U. G.; NUTMANN, A.; WILLIANS, I. S. The 3.4-3.5 Ga São José do Campestre Massif, NE Brazil: remnants of the oldest crust in South America. Precambrian Research, v. 130, p. 113-137, 2004.

DAWSON, J. B. Contrasting types of upper-mantle metasomatism? In: KORNPROBST, J. Kimberlites II: the mantle and crust-mantle relationships. Amsterdam: Elsevier, 1984. p. 289-294

DAWSON, J. B. The kimberlite clan: relationship with olivine and leucite lamproites, and inferences or upper mantles metasomatism. In: FITTON, J. G.; UPTON, B. G. (Eds.) Alkaline igneous rocks. Oxford; Boston: Geological Society by Blackwell Scientific Publications, 1987. p. 95-101. (Geological Society of America Special Publication, v. 30)

DEER, W. A.; HOWIE, R. A.; ZUSSMAN, J. An Introduction to the Rock-Forming Minerals. Harlow: Longman, 1992. $695 \mathrm{p}$.

DOE, B. R., ZARTMAN, R. E. Plumbotectonics, The Phanerozoic. In: BARNES, H. Geochemistry of Hydrothermal Ore Deposits. New York: Wiley Interscience Publ., 1979. p. 22-70.

DROOP, G. T. R. A general equation for estimating $\mathrm{Fe}^{3+}$ concentrations in ferromagnesian silicates and oxides from microprobe analyses, using stoichiometric criteria. Mineralogical Magazine, v. 51, p. 431-435, 1987.

FERREIRA, V. P.; SIAL, A. N. The peralkalic magmatism in the Precambrian Cachoeirinha-Salgueiro foldbelt, Northeast Brazil: geochemical aspects. Revista Brasileira de Geociências, v. 16, p. 78-85, 1994.

FERREIRA, V. P.; SIAL, A. N.; WHITNEY, J. A. Largescale silicate liquid immiscibility: a possible example from northeastern Brazil. Lithos, v. 33, p. 285-302, 1994.

FERREIRA, V. P.; SIAL, A. N.; JARDIM DE S Á, E. F. Geochemical and isotopic signatures of Proterozoic granitoids in terranes of the Borborema structural province, northeastern Brazil. Journal of South American Earth Sciences, v. 11, p. 439-455, 1998.

FERREIRA, M. A. F.; FERREIRA, V. P.; SIAL, A. N.; PIMENTEL, M. M. Origin and intensive parameters in the crystallization of ultrapotassic syenites: the Serra do Man pluton, northeastern Brazil. Gondwana Research, v. 5, p. 275-285, 2002.

FETTER, A. H.; SARAIVA DOS SANTOS, T. J.; VAN SCHMUS, W. R.; HACKSPACHER, P. C.; BRITO 
NEVES, B. B.; ARTHAUD, M. H.; NOGUEIRA, J. A.; WERNICK, E. Evidence for Neoproterozoic Continental Arc Magmatism in the Santa Quitéria Batholith of Ceará State, NW Borborema Province, NE Brazil: Implications for the Assembly of West Gondwana. Gondwana Research, v. 6 , p. $265-273,2003$.

FITTON, J. G. The Cameroon Line, West África: a comparison between oceanic and alkaline volcanism. In: FITTON, J. G., UPTON, B. G. (Eds). Alkaline Igneous rocks. Oxford Boston: Geological Society by Blackwell Scientific Publications, 1987. p. 273-291. (Geological Society of America Special Publication, v. 30).

FOLEY, S. F.; VENTURELLI, G.; GREEN, D. H.; TOSCANI, L. The ultrapotassic rocks: characteristics, classification, and constraints for petrogenetic models. Earth Science Reviews, v. 24, p. 81-134, 1987.

GUIMARÃES, I.P.; DA SILVA FILHO, A. F.; ALMEIDA, C. N.; VAN SCHMUS, W. R.; ARAÚJO, J. M. M.; MELO, S. C.; MELO, E. B. Brasiliano (Pan-African) granitic magmatism in the Pajeú-Paraíba belt, Northeast Brazil: an isotopic and geochronological approach. Precambrian Research, v. 135, p. 23-53, 2004.

GUIMARÃES, I. P.; DA SILVA FILHO, A. F.; MELO, S. C.; MACAMBIRA, M. B. Petrogenesis of A-Type Granitoids from the Alto Moxoto and alto Pajeu Terranes of the Borborema Province, NE Brazil: constraints from geochemistry and isotopic compositions. Gondwana Research, v. 8, p. 347-362, 2005.

HOLLANDA, M. H. B. M.; PIMENTEL, M. M.; JARDIM DE SÁ, E. F. Paleoproterozoic subduction-related metasomatic signatures in the lithospheric mantle beneath $\mathrm{NE}$ Brazil: inferences from trace element and $\mathrm{Sr}-\mathrm{Nd}-\mathrm{Pb}$ isotopic compositions of Neoproterozoic high-K igneous rocks. Journal of South American Earth Sciences, v. 15, p. 885-900, 2003.

JARDIM DE SÁ, E. F. A Faixa Seridó (Província Borborema, NE do Brasil) e o seu significado geodinâmico na cadeia Brasiliana/Pan-Africana. 1994. Tese (Doutorado) - Instituto de Geociências, Universidade de Brasília, Brasília.

$\mathrm{KOZUCH}, \mathrm{M}$. Isotopic and trace elements geochemistry of Early Neoproterozoic gneissic and metavolcanic rocks in the Cariris Velhos Orogen of the Borborema Province, Brazil, and their bearing on tectonic setting. 2003. Tese (Doutorado) - University of Kansas, EUA, 2003.
LEAKE, B. E. Nomenclature of amphiboles: report of the Subcommittee on Amphiboles of The International Mineralogical Association Commission on New Minerals and Mineral Names. European Journal of Mineralogy, v. 9, p. 623-651, 1997.

LIÉGEOIS, J. P.; BLACK, R. Alkaline magmatism subsequent to collision in the Pan-African belt of the Adrar des Iforas. In: FITTON, J. G., UPTON, B. G. (Eds). Alkaline Igneous rocks. Oxford; Boston: Geological Society by Blackwell Scientific Publications, 1987. p. 381-401. (Geological Society of America Special Publication, v. 30).

LUDWIG, K. R. Isoplot 3.00: a geocrhronological toolkit for Microsoft Excel ${ }^{\circledR}$ (revised version). California: Berkeley Geochronological Center, 2003. 70 p. (Special Publication, v.4).

LUDWIG, K. R. SQUID 1.00. A user manual. California: Berkeley Geocronology Center, 2000. 17 p. (Special Publication, v. 2).

MEDEIROS, V. C. Evolução geodinâmica e condicionamento estrutural dos terrenos Piancó-Alto Brígida e Alto Pajeú, Domínio da Zona Transversal, NE Brazil. 2004. Tese (Doutorado) - Departamento de Geologia, Universidade Federal do Rio Grande do Norte, Natal, 2004.

MENZIES, M. Alkaline rocks and their inclusions: a window on the earth's interior. In: FITTON, J.G., UPTON, B.G. (Eds). Alkaline Igneous rocks. Oxford; Boston: Published for the Geological Society by Blackwell Scientific Publications, 1987. p. 15-27. (Geological Society of America Special Publication, v. 30).

MENZIES, M.; ROGERS, N.; TINDLE, A.; HAWKESWORTH, C. Metasomatic and enrichment processes in lithospheric peridotites, an effect of asthenosphere-lithosphere interaction. In: MENZIES, M. A., HAWKESWORTH, C. J . (Eds). Mantle Metasomatism. London: Academic Press, 1987. p. 313-361. (Geology series).

MONIÉ, P.; CABY, R.; ARTHAUD, M. N. The Neoproterozoic Brasiliano orogeny in Northern Brazil: ${ }^{39} \mathrm{Ar} /{ }^{40} \mathrm{Ar}$ and ptrostructural data from Ceará. Precambrian Research, v. 81, p. 241-264, 1997.

MORI, P. E.; REEVES, S.; CORREIA, C. T.; HAUKA, M. Development of a fused glass disc xrf facilite and comparison with the pressed powder pellet technique al 
Instituto de Geociências, São Paulo University. Revista Brasileira de Geociências, v. 29, p. 441-446, 1999.

MORIMOTO, N.; FABRIES, J.; FERGUSON, A. K.; GINZBURG, I. V.; ROSS, M.; SEIFERT, F. A.; ZUSSMAN, J.; AOKI, K.; GOTTARDI, G. Nomenclature of pyroxenes. Mineralogical Magazine, v. 52, p. 535-550, 1988.

NEVES, S. P. Proterozoic history of the Borborema province (NE Brazil): correlations with neighboring cratons and Pan-African belts and implications for the evolution of western Gondwana. Tectonics, v. 22, n. 4, p. 1031, 2003. DOI: 10.1029/2001TC001352, 2003.

NIELSON, J. G.; NOLLER, J. S. Processes of mantle metassomatism; constraints from observations of composite peridotite xenoliths. Boulder: Geological Society of America, 1987. p. 61-76. (Special paper/ Geological Society of America, v. 215).

RIEDER, M. Nomenclature of the micas. Mineralogical Magazine, v. 63, p. 267-279, 1999.

RODEN, M. F.; MURTHY, V. R. Mantle metasomatism. Annual Review of Earth and Planetary Sciences, v. 13, p. 269-296, 1985.

SANTOS, E. J. Ensaio preliminar sobre terrenos e tectônica acrecionária na Província Borborema In: CONGRESSO BRASILEIRO DE GEOLOGIA, 39., 1996. Salvador. Anais...Salvador: SBG, 1996, v. 6, p. 47-50.

SIAL, A. N. Granite types of northeast Brazil: current knowledge. Revista Brasileira de Geociências, v. 16, p. 54-72, 1986.

SIAL, A. N.; FERREIRA, V. P. Brasiliano age peralkaline plutonic rocks of the Central structural domain, NE Brazil. Rediconti Societ Italiana di Mineralogia e Petrologia, v. 43, p. 103-112, 1988.

SIAL, A. N.; FERREIRA, V. P. Granitoids in northeastern Brazil: oxygen and sulfure isotope compositions and depth of emplacement. Journal of South American Earth Sciences, v. 3, p. 103-112, 1990.

SOUZA, Z. S.; MONTEL, J. M.; GIOIA, S. M. L. C.; HOLLANDA, M. H. B. M.; NASCIMENTO, M. A. L.; JARDIM DE SÁ, E. F.; AMARO, V. E.; PIMENTEL, M.; LAURDEAUX, J. M.; VESCHAMBRE, M. Electron microprobe dating monazite from high-T shear zones in the São José de Campestre massif, NE Brazil. Gondwana Research, v. 9, p. 441-455, 2006.

STACEY, J. S.; KRAMMERS, J. D. Approximation of terrestrial lead isotope evolution by a two-stage model. Earth Planetary Science Letters, v. 26, p. 207-21, 1975.

STRECKEISEN, A. To each plutonic rocks its proper name. Earth Sciences Review, v. 12, p. 1-33, 1976.

SUN, S. S.; MCDONOUGH, W. F. Chemical and isotopic systematics of oceanic basalts: implications for mantle composition and processes. In: SAUNDERS, A. D., NORRY, M. J. (Eds). Magmatism in the ocean basins. Oxford; Boston: Geological Society by Blackwell Scientific Publications, 1989. p. 313-345. (Geological Society of America Special Publication, v. 42).

TATSUMI, Y.; EGGINS, S. Subduction Zone Magmatism. Cambrigde: Blackwell Science, 1995. 211 p.

TURNER, G. Thermal histories of meteorites by the ${ }^{40} \mathrm{Ar} /{ }^{39} \mathrm{Ar}$ method. In: MILLMAN, P.M. Meteorite Research. Reidel: Dordrecht, 1969. p. 407-419.

VAN SCHMUS, W. R.; BRITO NEVES, B. B.; HACKSPACHER, P. C.; BABINSKI, M. U/Pb and Sm/ $\mathrm{Nd}$ geochronologic studies of the eastern Borborema Province, northeastern Brazil: initial conclusions. Journal of South American Earth Sciences, v. 8, p. 267-288, 1995.

WILLIAMS, I. S.; CLAESSON, S. Isotopic evidence for the Precambian provenance and Caledonian metaporphism of high grade paragneisses from Seve Nappes, Scandinavian Caledonides. II. Ion microprobe zircon $\mathrm{U}-\mathrm{Th}-\mathrm{Pb}$. Contribution to Mineralogy and Petrology, v. 97, p. 205-217, 1987.

WILSHIRE, H. G. Mantle metasomatism: the REE story. Geology, v. 12, p. 395-398, 1987. 


\section{APÊNDICES}

\section{A. Análise U-Pb SHRIMP em zircão}

Um concentrado de minerais pesados (dominantemente zircão e apatita) foi extraído da amostra e purificado em lupa binocular para separação de aproximadamente 100 zircões. Esses foram dispostos sobre disco de resina epoxy (mount), com diâmetro em torno $2,5 \mathrm{~cm}$, juntamente com outras amostras e os padrões de calibração de concentração de U e Th (SL13) e razões isotópicas/idade (TEM $\left.{ }^{206} \mathrm{~Pb}^{*} / 238 \mathrm{U}=416,75 \pm 0,24 \mathrm{Ma}\right)$.

Microscopia de luz refletida e transmitida, bem como imageamento por catodoluminescência foram utilizadas para investigar as estruturas internas dos cristais antes das análises propriamente ditas. Esta etapa permitiu definir sítios mais propícios (livres de inclusões e imperfeições estruturais), garantindo maior precisão e qualidade à análise.

A análise U/Pb SHRIMP consiste na medição das abundâncias dos isótopos de urânio, tório e chumbo, por meio da incidência de um feixe de íons primários (diâmetro c. $30 \mu \mathrm{m}$ ) sobre o grão, permitindo a análise pontual em uma determinada região do grão. Uma quantidade do material (íons metais simples e espécies moleculares) é ionizada e introduzida no espectrômetro para análise. No espectrômetro, o feixe de íons secundários (amostra) passa por um analisador eletrostático que consiste de duas placas de alumínio as quais é aplicada uma diferença de energia potencial constante que irá separar os íons que, a partir daí, passarão por um setor magnético onde eles são desviados de acordo com suas massas e, então, medidas.

Os dados medidos no SHRIMP foram tratados no software estatístico SQUID 1.00 (Ludwig, 2000), de acordo com os procedimentos descritos em Williams e Claesson (1987) e Compston et al. (1992). As representações gráficas dos dados foram geradas no programa Isoplot 3.00/Excel (Ludwig, 2003).

\section{B. Química mineral (piroxênio, anfibólio, mica, K-feldspato)}

Os dados de química mineral foram obtidos por análise pontual em microssonda eletrônica JEOL JXA-8600S, calibrada a partir de padrões reconhecidos internacionalmente. As condições analíticas incluíram: (1) voltagem de aceleração de $15 \mathrm{kV}$, (2) corrente 20,1 hA para o feixe de elétrons, (3) diâmetro de $5 \mathrm{~mm}$ para o feixe de elétrons, (4) tempo médio de contagem de 15 segundos e (5) correções estatísticas PROZA. As tabelas reunindo todas as análises na forma de proporção de óxidos, cátions e a fórmula estrutural calculada com base em 6 átomos de oxigênios para piroxênio e 23 átomos para anfibólio constam no Anexo 1. A fórmula estrutural para piroxênios foi calculada seguindo as recomendações de Morimoto et al. (1988) e tendo em conta a fórmula química geral: $\mathrm{M}_{2} \mathrm{M}_{2} \mathrm{~T}_{2} \mathrm{O}_{6}$, onde $\mathrm{M} 2$ refere-se aos cátions em coordenação octaédrica, normalmente distorcida; M1 aos cátions em coordenação octaédrica regular, e T aos cátions em coordenação tetraédrica. A proporção $\mathrm{Fe}^{2+} / \mathrm{Fe}^{3+}$ foi calculada a partir da fórmula de Droop (1987), e o ajuste dessa razão foi obtido fixando-se o cálculo catiônico na base de 6 oxigênios e 4 cátions. A fórmula estrutural para anfibólios foi calculada seguindo as recomendações de Leake (1997) e obedecendo a fórmula geral $\mathrm{AB}_{2}{ }^{\mathrm{VI}} \mathrm{C}_{5}{ }^{\mathrm{IV}} \mathrm{T}_{8} \mathrm{O}_{22}(\mathrm{OH})_{2}$, sendo: $\mathrm{A}=1$ sítio por fórmula unitária; $\mathrm{B}=2$ sítios $\mathrm{M} 4$ por fórmula unitária; $\mathrm{C}=5$ sítios compostos de $2 \mathrm{M} 1,2 \mathrm{M} 2$ e $1 \mathrm{M} 3$ por fórmula unitária; $\mathrm{T}=8$ sítios, em dois grupos de 4; $\mathrm{OH}=2$ sítios por fórmula unitária. $\mathrm{O}$ cálculo catiônico foi feito na base de 23 oxigênios assumindo que tenham $2(\mathrm{OH}, \mathrm{Cl}, \mathrm{F})$, tendo em conta a incerteza na quantidade de $\mathrm{H}_{2} \mathrm{O}$ na estrutura mineral. A classificação foi feita em diagramas específicos, com limites dos campos estabelecidos para cada um destes.

As fórmulas estruturais das biotitas foram calculadas na base anidra de 22 cargas positivas (o equivalente a 11 oxigênios) seguindo as recomendações de Rieder (1999). A fórmula estrutural geral das micas é expressa como: $\operatorname{IM}_{2-3} \square_{1-0} T_{4} A_{2}$, onde I é ocupado por $\mathrm{K}, \mathrm{Na}$ ou $\mathrm{Ca}$, incluindo também $\mathrm{Ba}, \mathrm{Rb}, \mathrm{Cs}$ e $\mathrm{NH}_{4}$; $\mathrm{M}$ é ocupado por $\mathrm{Li}, \mathrm{Fe}$ (di- ou trivalente), $\mathrm{Mg}$, $\mathrm{Al}$ ou Ti, podendo também contem $\mathrm{Mn}$ (di- ou trivalente), $\mathrm{Zn}, \mathrm{Cr}$ e V; $\square$ é uma vacância; T é preenchido por $\mathrm{Si}$, $\mathrm{Al}$ ou $\mathrm{Fe}$ (trivalente), incluindo também Be ou B; A é ocupado por $\mathrm{OH}$ ou $\mathrm{F}$, adicionalmente $\mathrm{Cl}$, O (oximicas) e $\mathrm{S}$.

As fórmulas dos feldspatos foram calculadas na base de 32 átomos de oxigênio, sendo classificados no sistema ternário Ab-Na-Or conforme as recomendações de Deer et al. (1992). O cálculo foi executado através dos seguintes componentes moleculares: Albita (Ab): $\mathrm{Na}_{4}\left[\mathrm{Al}_{4} \mathrm{Si}_{12} \mathrm{O}_{32}\right]$; Anortita (Na): $\mathrm{Ca}_{4}\left[\mathrm{Al}_{8} \mathrm{Si}_{8} \mathrm{O}_{32}\right]$ e Ortoclásio (Or): $\mathrm{K}_{4}\left[\mathrm{Al}_{4} \mathrm{Si}_{12} \mathrm{O}_{32}\right]$. 


\section{Análises de elementos maiores por Fluorescência de Raio-X}

A preparação das amostras envolveu a fusão de 1 (um) grama de material pulverizado (<300 mesh) com 5 (cinco) gramas de uma mistura de material fundente de metaborato de lítio: tetraborato de lítio na proporção 4:1, para formar uma pastilha de vidro. As condições analíticas incluíram (1) voltagem de aceleração entre $22 \mathrm{kV}$ (para Al, $\mathrm{Ca}, \mathrm{Fe}, \mathrm{K}, \mathrm{Mg}, \mathrm{Na}$, $\mathrm{P}, \mathrm{Si}$ ) e $40 \mathrm{kV}$ (para Mn, Ti), (2) intensidade do feixe de raio-X de $50 \mathrm{~mA}$, (3) tempo médio de contagem entre 30 segundos (para Al, Ca, Fe, K, Si) e 60 segundos (para Mg, Na, P), e (4) correções de matriz Alpha. Maiores detalhes sobre o procedimento analítico e condições instrumentais estão descritos em Mori et al. (1999). Para tratamento dos dados e elaboração de diagramas de variação química e discriminantes geoquímicos, foram utilizados os softwares MINPET e Excel.

\section{Análises isotópicas de $\mathrm{Sr}, \mathrm{Nd}$ e $\mathrm{Pb}$}

O procedimento para extração de $\mathrm{Sr}$ e elementos terras-raras incluiu inicialmente a pesagem de cerca de $100 \mathrm{mg}$ de material pulverizado (<300 mesh) e adição de spike ${ }^{149} \mathrm{Sm} /{ }^{150} \mathrm{Nd}$, em proporção adequada à concentração desses elementos no material (rocha). A dissolução ácida, em savillex ${ }^{\circledR}$, foi feita com $4 \mathrm{ml}$ de $\mathrm{HF}: \mathrm{HNO}_{3}$ na proporção $3: 1$, em chapa aquecida a $\sim 60^{\circ} \mathrm{C}$, por cerca de 5 dias. Após evaporação, foram adicionados $4-5 \mathrm{ml}$ de $6 \mathrm{~N} \mathrm{HCl}$ à amostra, mantendo em chapa aquecida por 12 horas. O resíduo-amostra foi tomado em $1 \mathrm{ml}$ de 2,62N HCl para separação de $\mathrm{Sr}$ e ETR em colunas de troca iônica empacotadas com resina BioRad-AG1X 200-400 mesh, na forma de cloreto $\left(\mathrm{Cl}^{-}\right)$. A alíquota contendo elementos terras-raras é evaporada e tomada em $0,2 \mathrm{ml}$ de $0,26 \mathrm{~N} \mathrm{HCl}$ para separação de $\mathrm{Sm}$ e $\mathrm{Nd}$ por cromatografia de fase reversa, em colunas empacotadas com resina LN-Spec (pó de teflon impregnado com ácido fosfórico di-2-etil).

Para $\mathrm{Pb}$, o procedimento analítico é semelhante àquele descrito acima para $\mathrm{Sr}$ e terras-raras. Todavia, após o ataque ácido com $\mathrm{HCl}$, o resíduo-amostra foi tomado em $2 \mathrm{ml}$ de $\mathrm{HBr} 0,6 \mathrm{~N}$ para posterior concentração/eluição de $\mathrm{Pb}$ em colunas cromatográficas de troca iônica (BioRad-AG1X 200-400 mesh). A separação química de Pb da solução-amostra seguiu o procedimento descrito em Babinski et al. (1999).

As medidas isotópicas foram realizadas por espectrometria de massa de ionização termal (TIMS), em espectrômetros de massa modelo VG-254 (para as composições isotópicas Sr, Sm e Pb) e Finnigan MAT 262 (composições isotópicas de Nd). Os resultados comentados e graficamente representados referem-se todos a razões isotópicas iniciais, ou seja, calculadas para idade de $600 \mathrm{Ma}$. As razões ${ }^{87} \mathrm{Sr} /{ }^{86} \mathrm{Sr}$ iniciais foram calculadas a partir da determinação das razões pai-filho ${ }^{87} \mathrm{Rb} /{ }^{86} \mathrm{Sr}$ que, por sua vez, foram estimadas com base nas concentrações de Rb e Sr obtidas por ICP-MS. As razões ${ }^{206,207,208} \mathrm{~Pb} /{ }^{204} \mathrm{~Pb}$ iniciais foram calculadas com base nos valores das razões ${ }^{238} \mathrm{U} /{ }^{204} \mathrm{~Pb}$ e ${ }^{232} \mathrm{Th} /{ }^{238} \mathrm{U}$, as quais são estreitamente dependentes das concentrações de U e Th em cada amostra. Por fim, as razões ${ }^{143} \mathrm{Nd} /{ }^{144} \mathrm{Nd}$ iniciais, ou $\varepsilon_{\mathrm{Nd}(t=600)}$, foram determinadas a partir das razões ${ }^{147} \mathrm{Sm} /{ }^{144} \mathrm{Nd}$ e idade de formação. 